\title{
DGU
}

DANMARKS GEOLOGISKE UNDERS $\emptyset$ GELSE - SERIE A - NR. 18 MILJØMINISTERIET · Geological Survey of Denmark

\section{Diagenesis of the Gassum Formation Rhaetian-Lower Jurassic, Danish Subbasin}

BY

HENRIK FRIIS

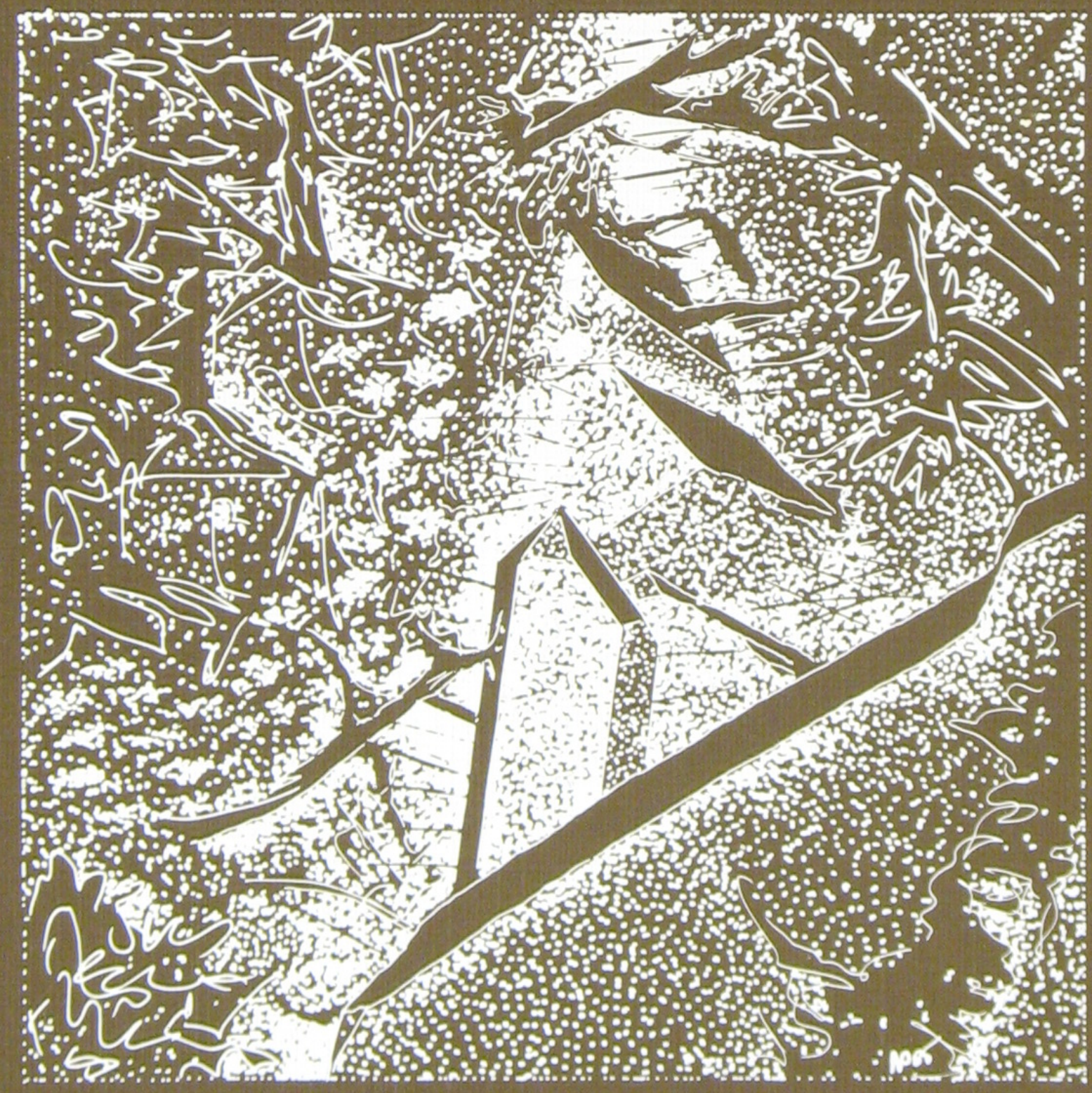

I kommission hos C. A. Reitzels forlag · København 1987 


\section{Diagenesis of \\ the Gassum Formation \\ Rhaetian-Lower Jurassic, \\ Danish Subbasin}

BY

HENRIK FRIIS

I kommission hos C. A. Reitzels forlag · København 1987 
Key words:

Gassum, Sandstone, Diagenesis, Triassic, Jurassic, Denmark.

with 4 plates

DGU Serie A nr. 18

ISBN 87-421-0754-7

ISSN 0901-0270

Oplag: 1200

Tryk: AiO Tryk as, Odense

Tegning: Lis Olesen og Eva Melskens

Foto: Forfatteren og John Sommer

Dato: 1988-1-18

Henrik Friis, Department of Geology

University of Aarhus, DK-8000 Aarhus C

Redaktion: Leif Banke Rasmussen

(C) Danmarks Geologiske Undersøgelse,

Thoravej 31, DK-2400 København NV 


\section{Preface}

The following report summarizes one part of the Energy Research Project (EFP-83) entitled "The Diagenesis of Clastic Reservoir Rocks in the Danish Underground". The project, which was funded by the Danish Ministry of Energy, extended from August, 1983 March, 1986 and was a cooperative effort between the Geological Survey of Denmark (DGU), Dansk Olie \& Naturgas A/S (DONG) and the Geological Institute of Aarhus University, Denmark. Project leadership was administrated by DGU; first by Stanley Fine through Sept. 1985 and thereafter by Palle Rubæk Andersen.

The purpose of the project was to document the detrital and diagenetic assemblages in four Triassic and Jurassic sandy formations and attempt to relate their diagenetic modifications to factors such as depth, provenance, lithofacies and tectonism. A database for the computer treatment of the many parametres used in a diagenesis study was also established.

The results of the project are presented in the following reports:
DGU publications:

Part 1: Bunter Sandstone Formation (Triassic) by Stanley Fine.

Part 2: Gassum Formation (Triassic/Jurassic) by Henrik Friis.

Part 3: Haldager Formation (Jurassic) by Palle Rubæk Andersen.

Internal Reports:

Documentation for computer programmel and pointcounting procedure developed for the Diagenesis Project by Stanley Fine.

Skagerrak Project. Mineralogical composition and diagenetic processes in Skagerrak Formation sandstones by Viggo Jensen.

Preliminary investigation on the diagenesis of the interval 1983-2167 m b.RT. (Skagerrak Formation ?), Vinding-1 by Palle Rubæk Andersen.

Project summary report to the Ministry of Energy by Stanley Fine and Palle Rubæk Andersen. 


\section{Contents}

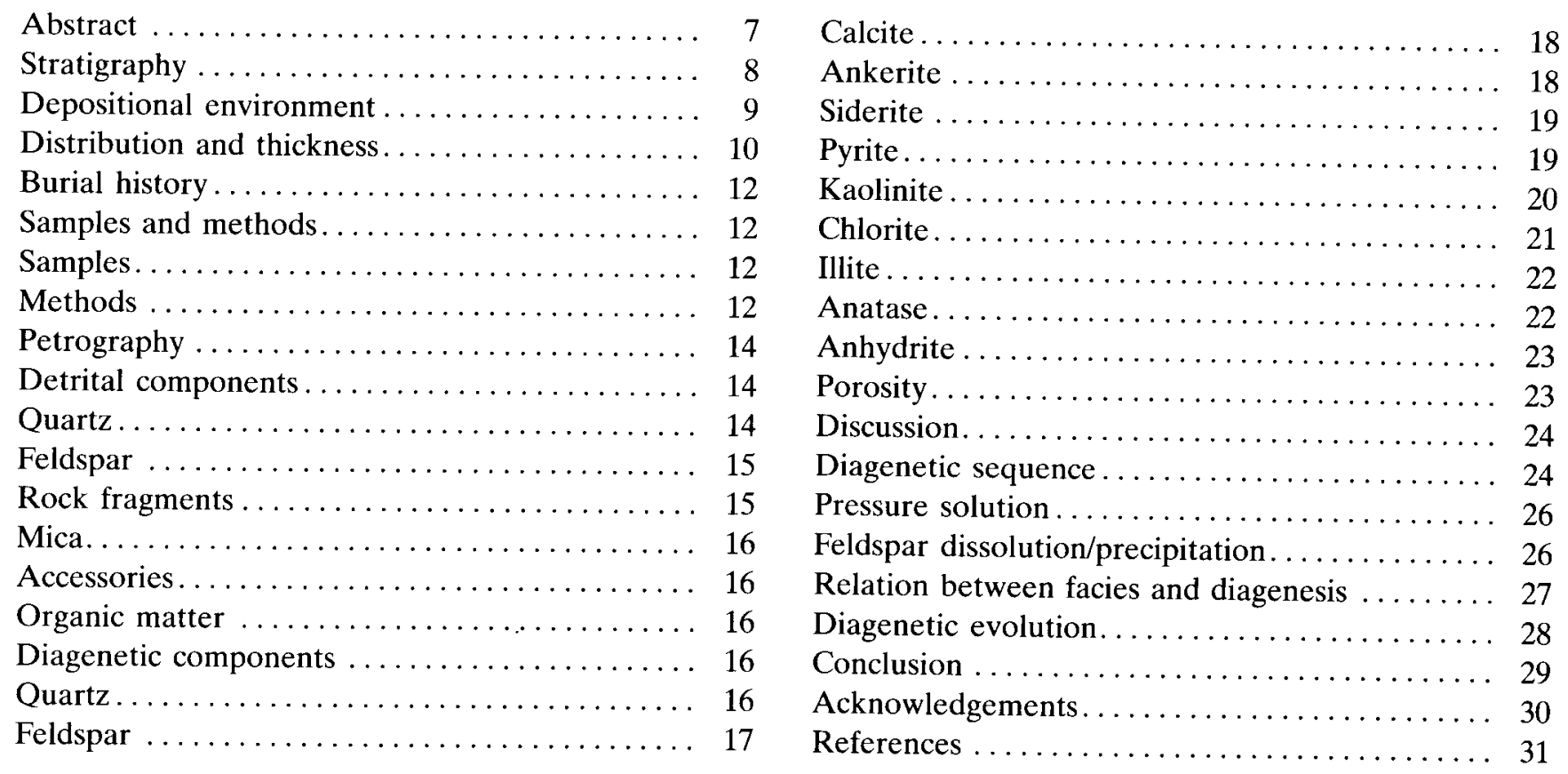




\section{Abstract}

The Upper Triassic-Lower Jurassic Gassum Formation is a shallow marine or deltaic sandstone body with intercalated mudstones. The sandstones are primarily arkoses and subarkoses, but the composition is strongly influenced by diagenesis. Depths of burial vary between ca. $550 \mathrm{~m}$ and $3350 \mathrm{~m}$, and the diagenetic modifications are strongly dependant on depth. The diagenetic pattern is also related to primary lithology.

At shallow depth of burial, the most important diagenetic changes are compaction, calcite cementation, formation of kaolinite, and dissolution of feldspar. In deeply buried parts of the formation, the most important diagenetic changes are reduction of primary and secondary porosity by strong cementation by quartz, albitization of partly dissolved feldspar and ankerite cementation. In chlorite-cemented parts, quartz cementation was inhibited, and here pressure solution occurred in deep parts of the formation. The porosity in these deeply buried samples may be reduced to secondary intragranular porosity in partly dissolved feldspar and intercrystalline porosity in clay mineral cements.

Other diagenetic minerals are siderite, pyrite, anhydrite, potassium feldspar and illite.

The diagenesis evolved through the eodiagenesis and the immature and semimature stages of mesodiagenesis, whereas mature stages have not been reached. 


\section{Stratigraphy}

The Gassum Formation was defined by Larsen (1966) to comprise the thick, mainly sandy wedge which was intersected between $1460 \mathrm{~m}$ and $1590 \mathrm{~m}$ below mean sea level in the Gassum 1 well (Fig. 2).

In 1978, Bertelsen redefined the formation on the basis of new well data; and he included the Gassum Formation in the Mors Group, which also includes the Vinding Formation (Bertelsen, 1980). According to the definition of Bertelsen (1978), the Gassum Formation also comprises some sandstone intercalations within the overlying Fjerritslev Formation.

In the central and southern part of the Danish Subbasin, the Gassum Formation may - on the basis of logmotifs - be subdivided into three members, G1 to G3 (Bertelsen, 1978). The G1 Member is a sandy, coarsening upwards sequence. The G2 Member is dominated by black to olive grey claystones and the G3 Member consists of grey and brownish silty claystones which grade upwards into fine-grained sandstones and siltstones (Bertelsen, 1978). Locally, other units may occur (Michelsen et al., 1981).

Towards the northeast, this subdivision of the Gassum Formation cannot be recognized. The formation is seen to interdigitate with the basal parts of the superposing Fjerritslev Formation (Bertelsen, 1978).

The deposition of the Gassum Formation was initiated in the Rhaetian, partly as a marginal facies to the brackish-marine Vinding Formation (Bertelsen, 1978), and continued into the Sinemurian, partly as a marginal facies to, and interfingering with, the Lower Jurassic Fjerritslev Formation (Michelsen, 1975; Bertelsen,

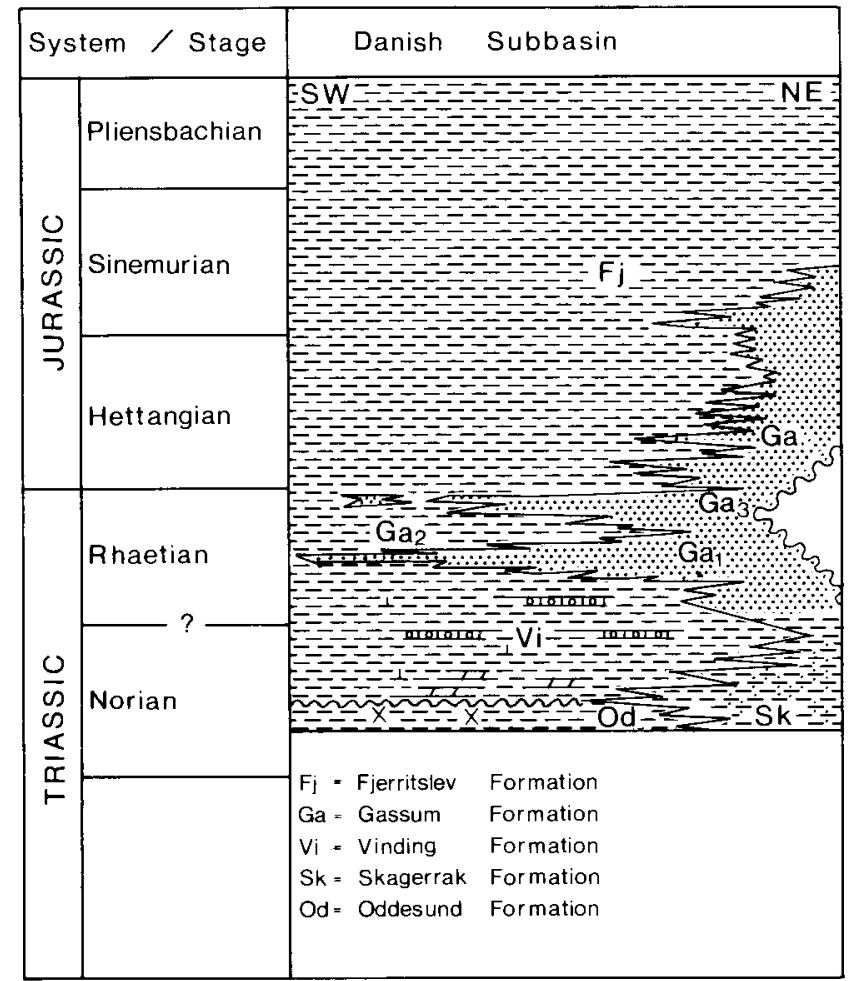

Fig. 1. Stratigraphic position of the Gassum Formation. Redrawn from Bertelsen (1978).

1978). In the northeastern part of the basin, the entire Gassum Formation is of Early Jurassic age (Michelsen, 1975; Bertelsen, 1978). The stratigraphic relations of the Gassum Formation are shown in Figure 1. 


\section{Depositional environment}

The depositional environment has been interpreted by Larsen (1966), Bertelsen (1978,1980), Michelsen and Bertelsen (1979) and Michelsen et al. (1981) as being dominantly deltaic or fluviodeltaic. The depositional model of Bertelsen (1978) implies that the upper part of the Vinding Formation constitutes the prodelta clays of a prograding delta, which deposited the basal parts of the Gassum Formation. The progradation of the delta is represented by the G1 Member, which is a deltaic coarsening upwards sandstone body grading upwards into distributary channel sandstones and interdistributary coal swamp deposits (Bertelsen, 1978). Also according to Bertelsen (1978), the black claystones of G2 Member were deposited in restricted environments on the drowned delta-plain, and during the successive regression, deltaic and limnic sediments of the G3 Member were deposited. The youngest parts of the Gassum Formation consist of shallow marine and deltaic sandstones deposited as marginal facies against Fennoscandia, corresponding to the basinal facies of the Fjerritslev Formation (Bertelsen, 1978; Michelsen \& Bertelsen, 1981).

Later Frandsen (personal communication, 1986) has revised the sedimentological data and interpreted the sediments of the Gassum Formation as being of shallow marine tidal platform origin. Based on a study of core samples, mainly from the Stenlille 1 well, Larsen et al. (1987) concluded that a major part of the Gassum Formation on Sjælland was deposited in tidal flat/subtidal shallow marine environments. The environmental interpretations give no specific basis for subdivision of sample material to describe the diagenetic processes in relation to depositional environment, and only a rough textural classification has been related to the petrographic descriptions. This classification includes $6 \mathrm{fa}-$ cies:

Facies 1: Large scale cross-bedded or horizontally bedded medium- to coarse-grained sandstone.

Facies 2: Large or small scale cross-bedded medium- to fine-grained sandstone.

Facies 3: Small scale cross-bedded or horizontally bedded fine-grained sandstone to siltstone.

Facies 4: Heterolithic, finely interlaminated sandstone/ siltstone/dark mudstone, flaser and lenticular bedding, small scale ripple cross-bedding.

Facies 5: Siltstone.

Facies 6: Mudstone. 


\section{Distribution and thickness}

The depositional pattern of the Gassum Formation was partly controlled by large scale tectonic movements during the Late Triassic to Early Jurassic. Following an Early Kimmerian reactivation of block faulting, a depocenter was developed northeastwards of the Fjerritslev Fault Zone (Fig. 2) and coarse clastics were shed from the Fennoscandian Borderzone into the Danish Subbasin (Bertelsen, 1978). The Mid Kimmerian tectonic phase resulted in regional uplift, and on the Ringkøbing-Fyn High erosion cut through the Fjerritslev Formation and probably also locally through the Gassum Formation (Michelsen \& Bertelsen, 1979). The original distribution of the Gassum Formation is not known. Bertelsen (1978) suggested that it also covered the Ringkøbing-Fyn High, whereas Larsen (1966) on the basis of heavy-mineral analyses concluded that parts of the Ringkøbing-Fyn High sourced those parts of the Gassum Formation which were deposited close to the High (Ullerslev Formation, sensu Larsen, 1966).

Movements of Zechstein salt were initiated in the Keuper (e.g. Madirazza, 1975) and served as a major control on the local thickness distribution and burial depths of the Gassum Formation.

The overall thickness of the formation varies according to the general subsidence pattern. Maximum thicknesses are found in the Aalborg Graben, in the northern part of Sjælland and the northern part of the North German Basin (Fig. 2; Michelsen et al. 1981). 


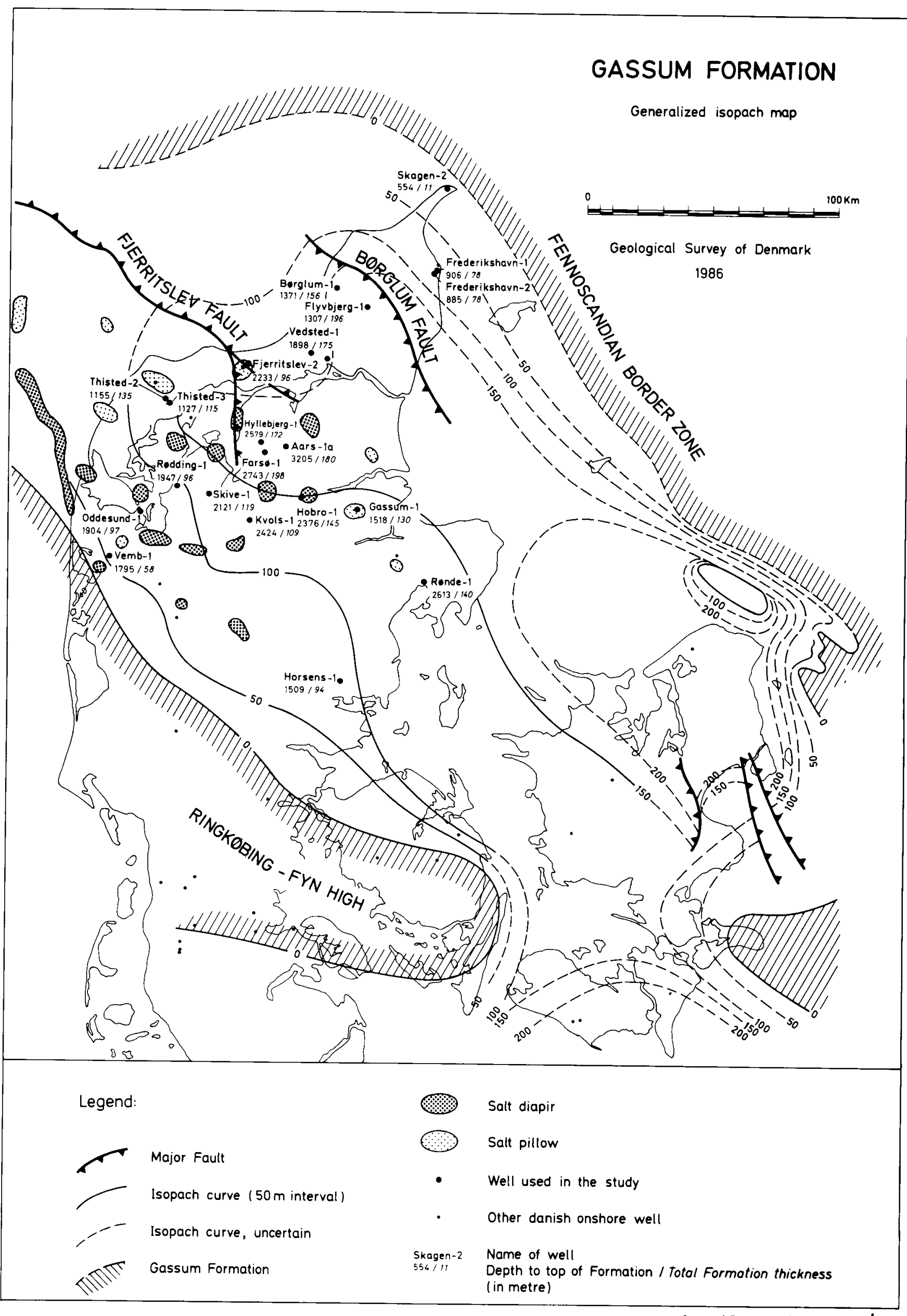

regnet af E. Melskens for Henrik Friis, Ärnus 


\section{Burial history}

During the Early Jurassic continued subsidence resulted in deposition of the Fjerritslev Formation, which may in places attain a thickness of more than $900 \mathrm{~m}$ (Michelsen, 1975). The Mid Kimmerian tectonic event resulted in regional uplift and erosion of the Fjerritslev Formation. Close to the Ringkøbing-Fyn High erosion probably cut through the Fjerritslev Formation and the Gassum Formation may have been exposed and eroded. In Middle Jurassic, subsidence was renewed in the central part of the Danish Subbasin, and thin Middle Jurassic to Lower Cretaceous sediments were deposited.

In the Late Cretaceous rapid subsidence took place and locally more than $2000 \mathrm{~m}$ of chalk was deposited. The maximum burial depth before the Late Cretaceous was in the scale of $1700 \mathrm{~m}$, while the present depth is probably more than $4000 \mathrm{~m}$ in the Himmerland Trough (Michelsen et al. 1981).

\section{Samples and methods}

\section{Samples}

The Gassum Formation is only accessible in the subsurface. Most of the samples included in this study are from conventional cores, a few are side-wall cores and further XRD has been performed on cutting samples.

The samples have been selected to cover a wide range of burial depths $(550-3350 \mathrm{~m})$ of the Gassum Formation within the NW part of the Danish Subbasin (i.e. mainly North Jylland wells, Figure 2). Samples from the southeastern part of the Danish area were not included in this study. The sampling concentrated on possible reservoir sections of the formation, and the G1 and G3 Members are strongly overrepresented as compared to other parts of the formation. This is partly a result of the availability of core samples, as the geothermal exploration wells made by DANSK OLIE OG NATURGAS A/S (D.O.N.G.) mainly provide core material from these members. The depth variation of the samples partly reflects the structural evolution of the Danish Subbasin with a deep central subsidence and shallow subsidence onto the Fennoscandian Borderzone. A number of wells were drilled close to salt structures, and depths in these cases are strongly influenced by salt movements.

A diagramatic presentation of the samples is shown in Figure 3.

\section{Methods}

The samples were analyzed by petrography, SEM, XRD and electron microprobe. The facies classification has been made by geologists at the Geological Survey of Denmark (D.G.U.).

Most thin sections were prepared from conventional cores and cut normal to bedding. Some of the thin sections were stained by Alizarin Red for carbonate identification and by Ferricyanide for feldspar identification (Friedman, 1971).

Electron microprobe analyses were carried out using a Jeol JMS 50A-Ortec 6200 Multichannel analyzer.

Scanning electron microscopy has been carried out on a Cambridge MK2, a Jeol JMS 840 and a Cambridge S180 with EDAX equipment.

XRD has been carried out on a large number of samples (Fig. 3), both for D.O.N.G. A/S and for D.G.U. Different laboratory procedures have been applied, 
and the results are not mutually comparable in detail. This is the case especially when clay mineralogical analyses are considered. XRD data are presented as percentage of total peak area (Figs. 5-8). Further analyses have been made on core material from Aars $1 \mathrm{~A}$ and Fars $\varnothing 1$ to distinguish more precisely between chlorite and kaolinite (Fig. 10).
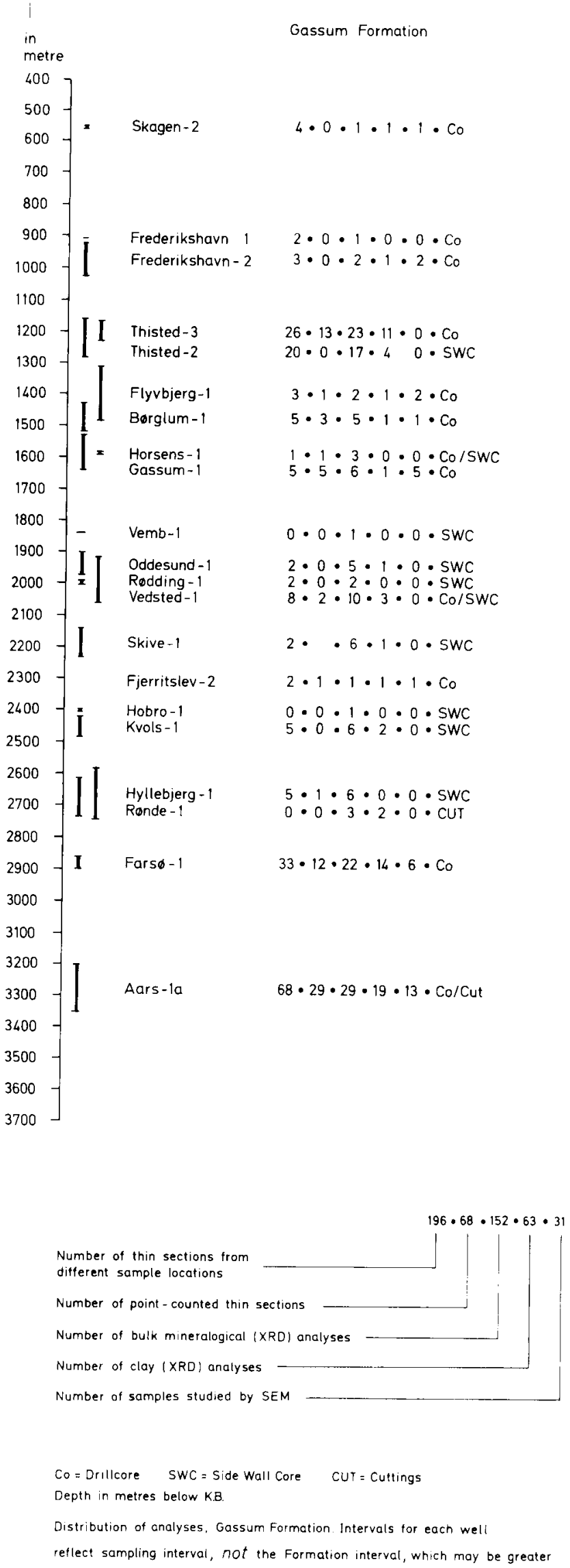

Fig. 3. Sampling profile, Gassum Formation. Numbers in legend are totals for each type of analyses. 


\section{Petrography}

\section{Detrital components}

\section{Quartz}

Quartz is the main component of all sandstone samples and constitutes $90-50 \%$ of the original framework grains. Monocrystalline grains dominate over polycrystalline varieties (represented in subequal amounts of distinctly metamorphic types and distinctly granitic types). Most of the grains have slight undulose extinction. Multiple cycle quartz grains with rounded overgrowths are rare.

In general, the original amount of quartz cannot be estimated with certainty, partly because of pervasive formation of quartz overgrowths which often cannot be distinguished from the detrital cores, and partly because of dissolution of less stable framework grains, especially feldspar. Further, replacement by carbonate is important in many samples. Therefore, the compositional clsssification shown in Figure 4 partly reflects the diagenetic development of the sandstones, and it is believed that the sandstones were originally richer in feldspar, as found in many shallow samples from the formation.

Formation of quartz overgrowths is the most common alteration of detrital quartz grains. Growth on monocrystalline varieties is by far the most common, but overgrowths were also noted on polycrystalline varieties.

In deeply buried samples pressure solution of framework quartz grains may be important. The pressure solution occurs in sandstone with relatively little quartz cement and dense grain coating chlorite.

In all levels of the formation, replacement by carbonate may be common. Both detrital quartz and diagenetic overgrowths may be replaced.

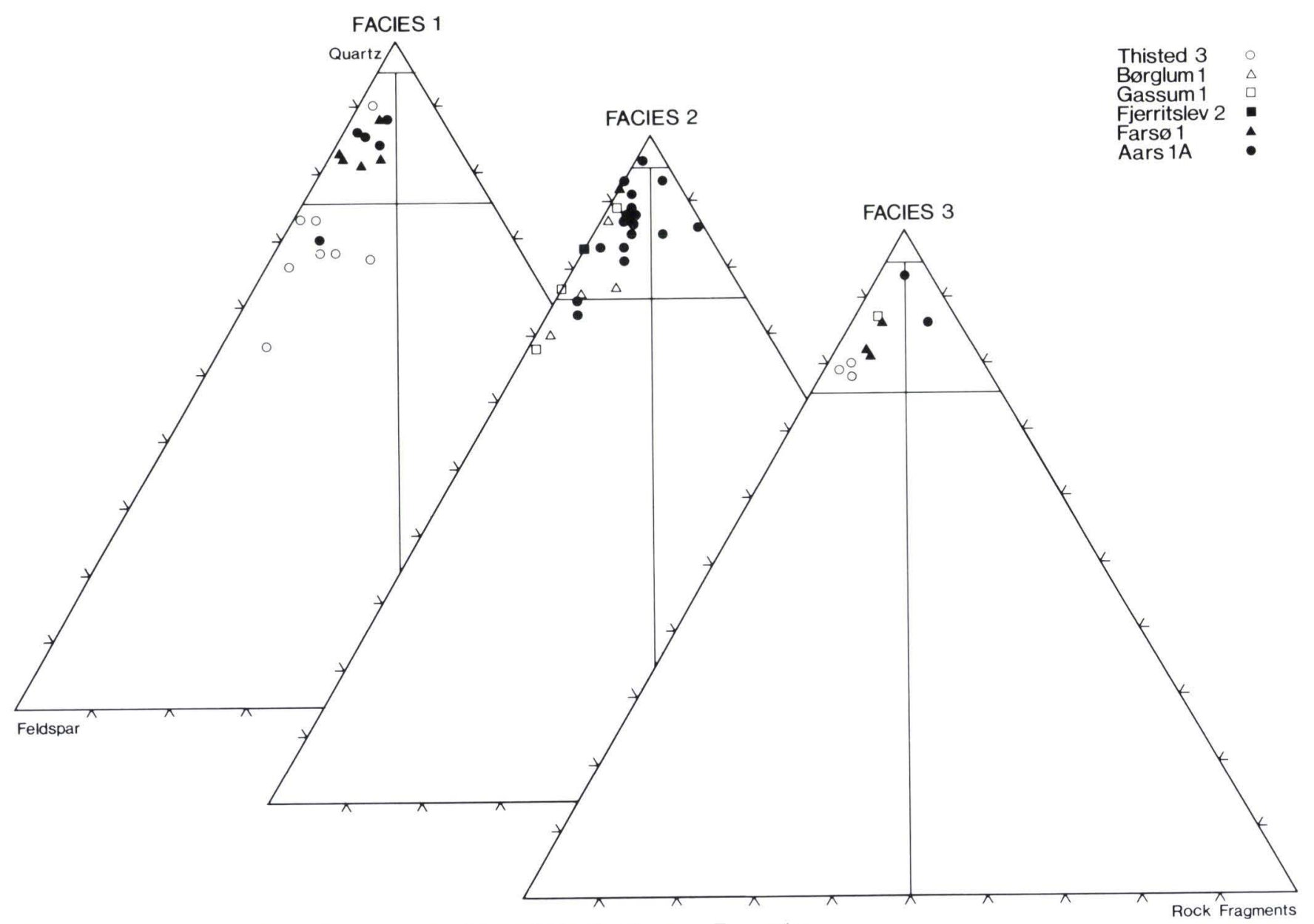

Fig. 4. Triangular plot of sandstone composition within the Gassum Formation. 


\section{Feldspar}

Feldspar makes up $10-25 \%$ of the framework grains in most samples, but the feldspar content is strongly influenced by diagenetic dissolution and replacement.

Alkali feldspars dominate and are represented by orthoclase, microcline and perthites. A large proportion of the feldspar grains are cloudy and partly seriticized. When feldspar grains carry overgrowths, only the detrital core is altered, whereas the overgrowth is quite unaltered and transparent.

The most important changes in feldspar framework grains are dissolution, replacement by kaolinite or carbonate, and diagenetic growth.

Partly dissolved feldspars occur in all stratigraphic levels of the formation, and all depths of burial. In general, intragranular dissolution appears to be most important, and produces skeletal remnants of the framework grains. These skeletons are often extremely fragile (Plate 1,A and B), but usually they remain intact and reveal the original size and shape of the feldspar grain (Plate 2,C). This clearly implies that the main compaction of the sediment occurred prior to the dissolution of the feldspar. As seen from Plate 1,C, the intragranular dissolution is controlled by the crystallographic organization of the feldspar grain, and probably reflects both differences in chemical composition (e.g. in perthites) and zones of physical weakness, such as cleavage cracks.

In general, it is not possible to estimate how many feldspar grains have been totally dissolved. Oversize pores occur, either open or filled with authigenic kaolinite. They probably originate from dissolution of feldspar. Where porelining chlorite is abundant, framework grains covered by the chlorite have in some cases been totally dissolved, and only the molds of porelining chlorite indicate the shape and size of the original framework grains. In such samples there may be a continuous range from partly to completely dissolved framework grains, and partly dissolved grains are always feldspar. Therefore it is inferred that some of the oversize pores originally contained feldspar grains, which have been completely dissolved. The presence of the intact chlorite porelining mold of dissolved framework grains demonstrates that the chlorite was precipitated before the feldspar dissolved.

There is no obvious compositional control on feldspar dissolution, although in some samples, where skeletal feldspar grains are abundant, the remnants are mainly alkali feldspar.

In most cases, the secondary porosity produced by differential dissolution of feldspars is still open and may represent the major part of the total porosity, but it may also be partly filled by later cement. This cement may invade the intragranular porosity marginally, as seen with quartz cement (Plate 1,A and B; Plate 2,G) and ankerite cement (Plate 4,H). Feldspar overgrowths also occur nucleating on small remnants of feldspar, gradually restoring the original grain (Plate 2,C). Although the authigenic feldspar occurs as small crystals which are apparently unconnected (Plate 2,C), their common crystallographic orientation clearly demonstrates that they nucleated on remnants of one crystal, and that these remnants still kept their original position without collapse or compactional displacement.

As seen from Plate 2,G, the growth of quartz into the intragranular secondary porosity occurred without further dissolution or replacement of the feldspar, which was simply enclosed by the growing quartz crystal. It is also seen that the quartz growth was not retarded during engulfment of the feldspar except in a narrow zone next to the feldspar remnants (Plate 1,B).

Ankerite cement may enter the intragranular porosity without distinct dissolution or replacement of the remnant feldspar (Plate 4,H). This is remarkable, as in most cases the ankerite is strongly replacive, also against feldspar (Plate 4,G).

Feldspar framework grains may be replaced by kaolinite or ankerite. Distinct replacement by kaolinite is only registered from samples in the Thisted 3 well and only in thin sand or siltstone intercalations in mudstone. In these samples the amount of preserved feldspar is lower than normal, and kaolinite is densely aggregated in framework positions, sometimes lined by early pore-lining pyrite. Kaolinite crystals are of equal size within each grain, but differ from grain to grain, and from grain to porefilling kaolinite.

In samples from Aars 1A and Farsø 1, some of the kaolinite occurs in oversize pores, and also in these cases, feldspar grains may have been replaced by kaolinite, but there is no evidence for a replacement rather than a post-dissolution precipitation of kaolinite.

Ankerite replacement of framework feldspar is pervasive in the deeply burried parts of the formation. In perthites, the replacement of the potassium phase may be faster, relative to the albite phase (Plate $4, G$ ).

Feldspar grains may to some degree be mechanically broken during compaction. In a few cases, quartz has grown into the opened cracks (Plate 1,D; Plate 4,D), and in such cases, it is evident that the compaction occurred prior to the major phase of quartz cementation.

Figure 5 shows the distribution of total feldspar as determined by XRD. In sandy facies (1-3), the content of feldspar decreases with depth down to about $2300 \mathrm{~m}$. At greater depths the content increases. XRD data indicate that alkali feldspars dominate above $2300 \mathrm{~m}$ whereas plagioclase (probably diagenetic, see "Feldspar dissolution/precipitation") is the most common feldspar at greater depths. In the fine-grained facies (4-6) the content of feldspar does not distinctly change with depth. 


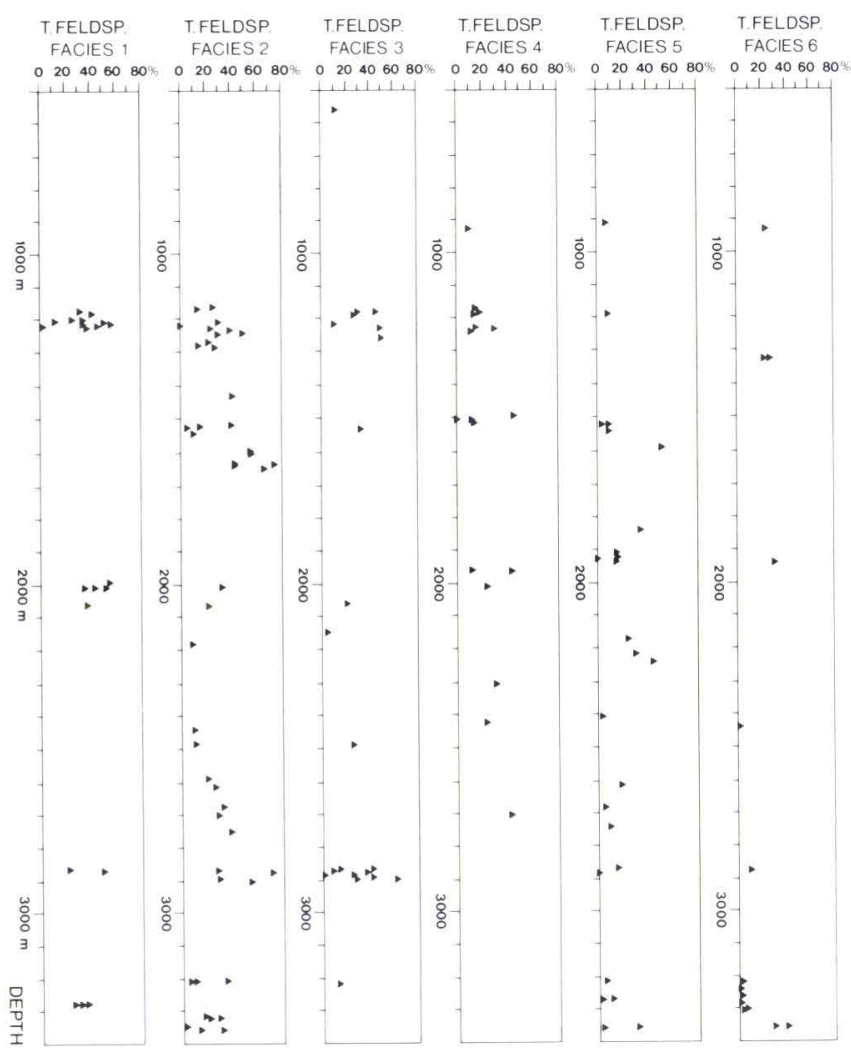

Fig. 5. Distribution of feldspar in relation to depth and lithology. Based on XRD-data, peak area-\%, bulk samples.

\section{Rock fragments}

Rock fragments generally constitute only a few percent of the framework detritals, but up to $10 \%$ is recorded in very coarse grained samples.

Most abundant rock types are granitic fragments (also including myrmekitic intergrown quartz/feldspar fragments), closely followed by micaceous metamorphic rocks. Volcanic and sedimentary rocks (including chert and mudrocks) are rare components.

Rock fragments may be strongly altered and partly dissolved, but occasionally feldspar crystals inside the rock fragment are remarkably well preserved as compared with feldspar grains in the same sample. Replacement by carbonate is common.

\section{Mica}

In the sandstones, micas constitute $0-2 \%$ of the framework grains. Muscovite is the most abundant mica, followed by chlorite and biotite. The micas are strongly altered, generally with expansion along the c-axis (Plate 4, E). Additionally chlorite and biotite are usually bleached, and in some cases siderite has precipitated in interlamellar positions (plate $4, E$ ). The mica grains may have been strongly deformed by compaction.

\section{Accessories}

In most samples heavy minerals constitute less than one percent, but they may locally be concentrated in thin streaks. Opaque heavy minerals are most abundant. Zircon and rutile are frequently noted while garnet and epidote are noted sporadically. Among the opaque minerals some are seen to be strongly dissolved, also with production of intragranular porosity. It has not been attempted to determine the opaque minerals, but the presence of authigenic anatase indicate that ilmenite was probably present and may have been partly dissolved. Sphene is also present in Danish Mesozoic sediments (Larsen, 1966) and may have contributed Ti, but has not been found in the thin sections.

When present, garnet and epidote are generally partly dissolved.

\section{Organic matter}

Particulate organic matter may occur abundantly in sandstones and coarse siltstones. It is often irregularly porous and associated with pyrite. In some cases pyrite is found in very large clusters, which have probably formed in the place of small twigs. Organic matter may be left in these positions but has often been completely removed.

\section{Diagenetic components}

\section{Quartz}

Authigenic quartz occurs as optically continuous overgrowths on detrital quartz grains. There are no observations to support the view that quartz grew independantly of existing quartz nuclei.

The amount of quartz overgrowths is strongly variable - from zero in shallow buried parts of the formation to $15 \%$ of the bulk volume in strongly cemented parts of the deeply buried parts of the formation. In most cases, however, the amount of quartz cement is probably underestimated as there is no distinct boundary between detrital core and overgrowth (fx. Plate 2,A).

In strongly cemented samples all quartz grains have overgrowths, but the largest overgrowths are seen on monocrystalline grains. The size of individual overgrowths may be up to $100 \mu \mathrm{m}$.

SEM shows that overgrowths are first formed as individual crystallites dominated by rhombohedral faces. These crystallites generally merge to form large single crystals, also dominated by rhombohedral faces, but occasionally prismatic faces are also well developed (Plate 1,A,D; Plate 3,A,F). This growth mode of quartz, described by Waugh (1970) and Pittman (1972) gives stepped crystal surfaces, and in advanced stages, 
the crystal faces are striated by shallow grooves (Plate $3, \mathrm{~F})$.

When quartz overgrowths abut other particles such as kaolinite crystals or skeletal feldspars, the quartz growth is retarded or inhibited closest to the contaminant, resulting in visible pits around it (Plate 1,B; Plate $3, G)$. It is not known how deep these pits extend into the quartz crystal, but they may be important for the transfer of ions during later stages of diagenesis.

The occurrence of quartz overgrowths is clearly controlled by depth with only few and very small overgrowths in samples from less than $1500 \mathrm{~m}$ and pervasive quartz cementation in samples from depths in excess of $1500 \mathrm{~m}$. In all levels, however, there are large variations in the amount of quartz cement. It is not always possible to explain this variation, but clearly, in some cases quartz cementation was inhibited by the presence of pore-lining chlorite (Plate 4,A). Apparently, the pore-lining chlorite has been dense enough to prevent quartz growths upon coated detrital quartz, and in these samples a large proportion of primary porosity was preserved until compactional diagenesis became important. During late compaction, some pore-linings were ruptured, and quartz grain surfaces became again exposed to the formation fluid, allowing formation of quartz overgrowths (Plate 3,C). In these cases, the quartz overgrowths expanded sidewards from small openings to partly or completely cover the pore-linings (Plate 3,A,B). Pressure solution contacts between quartz grains are common (Plate 3,B,D) and demonstrate that this compaction was related to deep burial conditions.

Also in chlorite-cemented samples authigenic quartz is only registered as overgrowths on detrital grains, and there is no independant growth of small quartz crystals as described from a Cretsceous sandstone with porelining apatite cement (Friis, 1985).

Quartz is commonly seen growing into the intercrystalline porosity of authigenic porefilling kaolinite booklets (Plate 2,A; Plate 3,D,G), which may themselves be totally included in the quartz crystal (Plate 2,A). This relation demonstrates that a major phase of quartz growth occurred after the formation of kaolinite. Kaolinite may also be included in feldspar overgrowths (Plate 2,A), and the compromise boundary between quartz- and feldspar overgrowths indicates simultaneous growth. It is not clear, either from thin sections or from SEM, whether some of the authigenic quartz is older than the kaolinite, but in many cases kaolinite crystals are not seen to grow directly upon the detrital core of quartz, and this may indicate that quartz growth also occurred prior to kaolinite precipitation (Plate $2, \mathrm{~A})$.

The distinct growth of quartz into the intragranular porosity of partly dissolved feldspar (Plate 1,A,B; Plate $2, \mathrm{G}$ ) demonstrates that a major phase of quartz cementation occurred after dissolution of the feldspar.
Both detrital grains and quartz overgrowths may be strongly replaced by ankerite (Plate $4, \mathrm{G}, \mathrm{H}$ ), and there is no evidence that quartz growth took place after cementation and replacement by ankerite.

\section{Feldspar}

The occurrence of authigenic feldspar is restricted to samples from depths of more than $1500 \mathrm{~m}$. Both potassium feldspar and albite are registered, but always as overgrowths on detrital feldspar grains. Feldspar overgrowths may be in optical continuity with the detrital core as is generally noted for potassium feldspar, but in most cases they are in optical discontinuity with the detrital core. This normally applies to albite overgrowths on alkali feldspar (Plate 2,B) or on plagioclase (Plate 2,D).

Although feldspar overgrowths may occur on as much as $90 \%$ of the detrital feldspar grains, they are volumetrically unimportant and constitute less that $1 \%$ of the bulk volume.

Authigenic potassium feldspar is noted from all depths below $1500 \mathrm{~m}$, whereas authigenic albite is only registered in samples from depths below approximately $2000 \mathrm{~m}$.

The feldspar overgrowths occur in two major textural modes. These are: a) thick rim cements up to $80 \mu \mathrm{m}$, which have grown in competition with quartz, as demonstrated by typical triplejunctions between quartzquartz-feldspar (Plate 2,A,B) and b) intragranular growth of small individual crystals on remnant skeletal fragments of detrital feldspar grains (Plate 2,C). In advanced stages, this growth mode may reconstruct the original grain. This growth mode is apparently comparable to the albitization process described by Walker (1984). However, the different stages of albite cementation clearly demonstrates that in this case the process involves a phase of dissolution (associated with the formation of a large volume of secondary porosity) followed by a phase of cementation (which strongly reduced the secondary porosity) rather than direct replacement of feldspar by albite. It is noteworthy that competition with quartz growth is only noted in connection with the extragranular growth of feldspar. Both extragranular and intragranular growth may occur on the same detrital grain (Plate 2,D).

Yde (1983) examined the chemical composition of feldspar overgrowths from the Gassum Formation in the wells Aars 1A, Fars $\varnothing 1$ and Gassum 1, and found that they are pure potassium feldspar or albite. He recorded no relationship between the composition of the detrital core and the composition of its overgrowth. In contrast, in perthite grains a distinct preferential growth of one of the two phases is seen. Plate $4, G$ 
shows a perthite with an albite overgrowth in optical continuity with one of the phases.

In general, the intragranular growth of albite may nucleate on very fragile skeletal remains of the original detrital grain (Plate 2,C). These remains are apparently separated by dissolution, but nevertheless the authigenic crystallites grew with identical crystallographic orientation. Although the detrital feldspar is almost completely destroyed, there has obviously been no serious disruption of the grain fragments after dissolution.

The textural relationships between authigenic feldspar and kaolinite demonstrate that kaolinite was precipitated before the feldspar. In general, the presence of kaolinite did not inhibit the growth of secondary feldspar, which has partly included the kaolinite (Plate 1,A,B), but in a few cases feldspar only formed on open surfaces (Plate 1,D). In one example, a detrital core has been replaced by kaolinite after the formation of a continuous rim-overgrowth but this is the only case where the formation of kaolinite clearly postdates the formation of feldspar. The authigenic overgrowth is not affected by the replacement.

Ankerite replacement affects both detrital cores and overgrowths, but there may be a preferential replacement dependant on composition. This is illustrated by Plate 4,G, where the albite phase of a perthite with its associated overgrowth is more resistant to replacement than the other perthite phase.

\section{Calcite}

Calcite occurs sporadically in samples from depths of less than $2000 \mathrm{~m}$. When present, the amount varies up to $35 \%$. The caicite is poikilotopic and partly replacive. Textural relations indicate that the cementation occurred after the first major phase of compaction and after initial quartz-cementation had taken place. This is demonstrated by a tight fabric of detrital grains, and a high proportion of long grain contacts. The high percentage of calcite in some samples does not represent the depositional porosity alone, but also replacement of framework grains.

XRD analyses show that calcite is present in small amounts in many samples, also from depths below 2000 $\mathrm{m}$ (Fig. 6). The fine-grained facies (4-6) tend to contain slightly more calcite than the sandy facies (1-3), when exception is made for strongly cemented samples (Fig. $8)$. It is also noted, that calcite is present below $2000 \mathrm{~m}$ only in fine-grained facies (Fig. 6).

\section{Ankerite}

The occurrence of ankerite is mainly restricted to depths below $2000 \mathrm{~m}$. Below this depth ankerite occurs

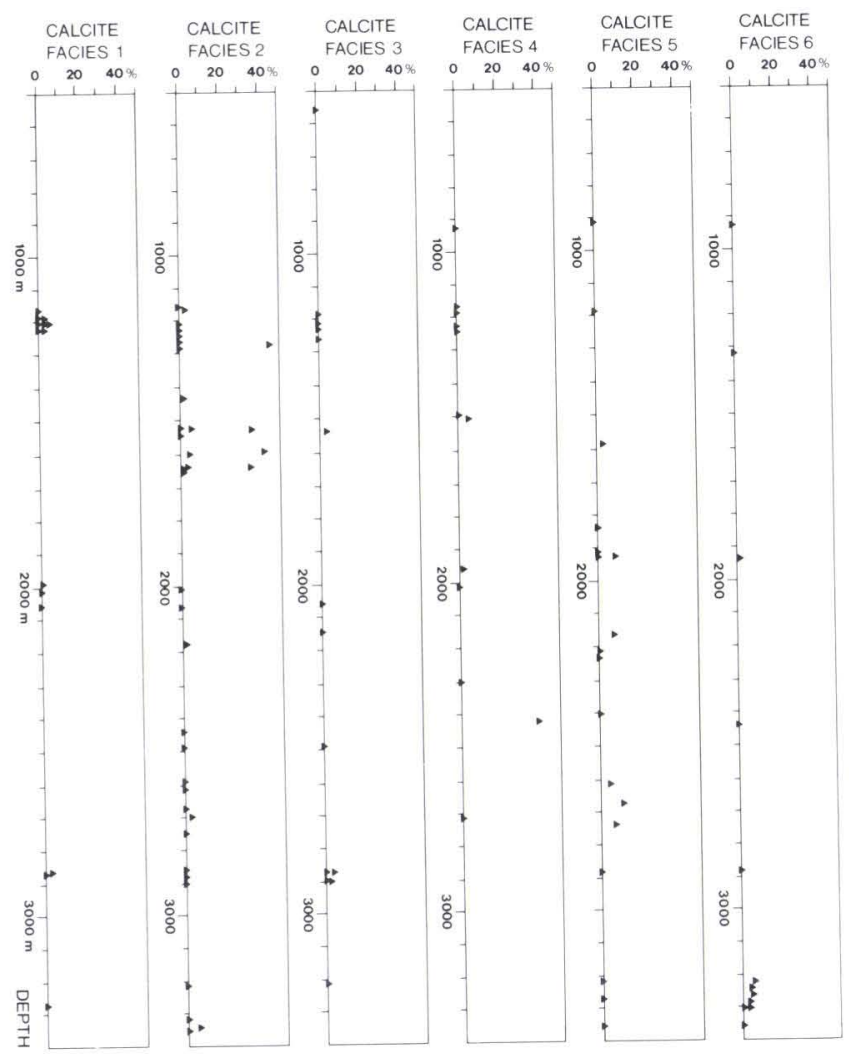

Fig. 6. Distribution of calcite in relation to depth and lithology. Based on XRD-data, peak area-\%, bulk samples.

in almost all samples. The amount varies from about $40 \%$ to less than $2 \%$. The ankerite is poikilotopic and may be strongly replacive (Plate $4, \mathrm{G}$ ).

Where ankerite is sparse, the crystals grow with welldefined rhombohedral faces, and may be only slightly replacive. This is shown in Plate $4, \mathrm{H}$, which also demonstrates that the ankerite has grown after the formation of quartz overgrowths, which are slightly replaced. It may also be seen, that the ankerite has grown after the partial dissolution of the feldspar grain, which is apparently only very slightly replaced, and remnants occur as inclusions inside the ankerite.

The composition of ankerite has been analyzed by electron microprobe (Table 1). The Fe/Mg-ratio is variable, as was also stated by Yde (1983), but the variation is related to a narrow Fe-rich rim rather than a depth control as suggested by Yde (1983). The Fe/Mg-ratio increases from about 0.5 in the interior part of crystals to about 1 in marginal parts of crystals (Fig. 9, Tables 1 and 2).

XRD analyses have demonstrated that dolomite/ankerite is present in a variety of lithologies and depths. The composition is only known to be ankerite from microprobe studies. On X-ray diffractograms the peak position of the (104) reflection indicate a composition closer to dolomite, and consequently the mineral is referred to as dolomite/ankerite. Figures 7 and 8 show that dolomite/ankerite is most abundant below $2000 \mathrm{~m}$ and in clean sandstones (facies 1-3). 


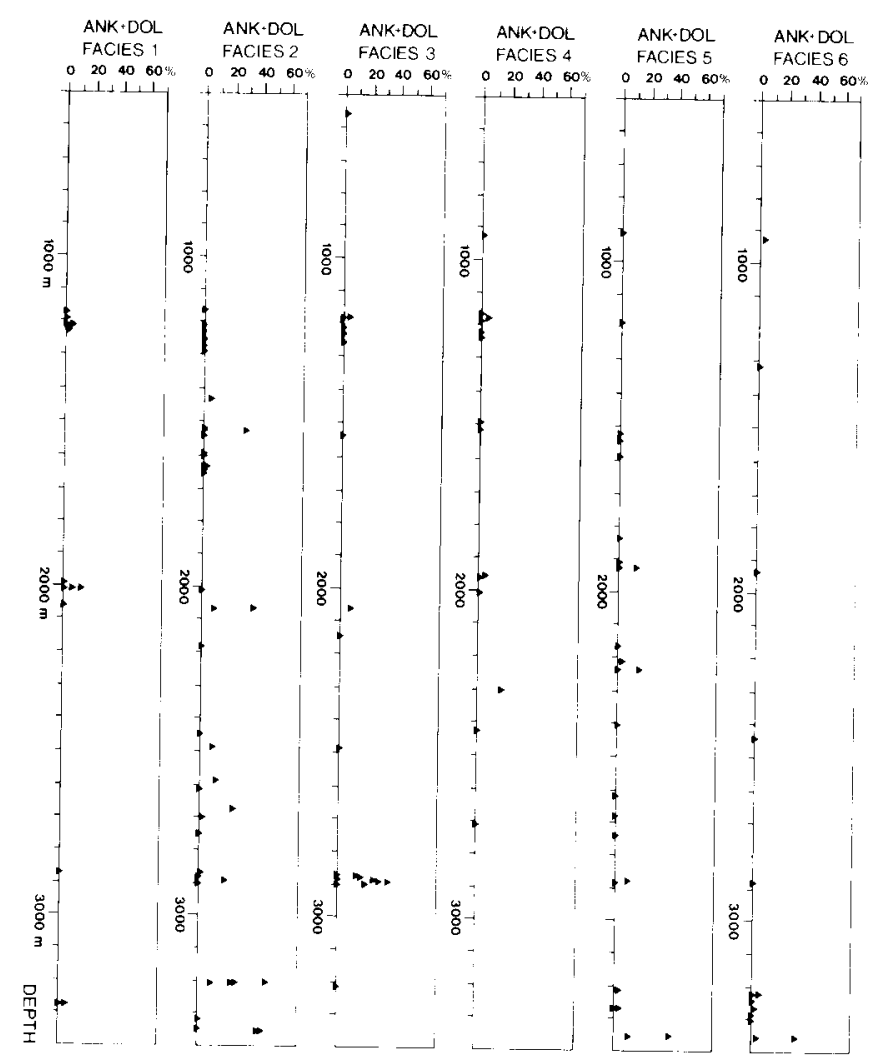

Fig. 7. Distribution of ankerite/dolomite in relation to depth and lithology. Based on XRD-data, peak area-\%, bulk samples.

\section{Siderite}

Siderite may occur abundantly in fine-grained sandstones and siltstones (Fig. 8), forming small euhedral crystals up to $50 \mu \mathrm{m}$ in size. In sandstones, they are strictly located in primary porosity and show no evidence of replacement. In most cases, the crystals show a zonation with a dark reddish core also of euhedral shape, and with a clear, colourless or slightly reddish shell. Yde (1983) analyzed crystals from the Gassum 1 well and found, that the cores consist of pure siderite, and that the shells consist of a mixed Ca-Mg-Mn-Fecarbonate. The zoned crystals may constitute up to $25 \%$ of the bulk volume, but generally makes up less than $2 \%$.

The second mode of occurrence is associated with altered micas, presumably biotite. Within these partly bleached and strongly expanded micas, numerous small euhedral yellowish carbonate crystals have grown between the lamellae (Plate 4,E) This carbonate is pure siderite as shown by the electron microprobe.

The third mode of occurrence has only been noted in a few samples from the Thisted 3 well (Plate 4,F). Pure siderite has grown in displacive spherolitic aggregates, which are densely clustered by pyrite in the interior part of the aggregate. A different type of spherolitic siderite consists of a core of $\mathrm{Mn}$-rich siderite with a corona of pure siderite. Apparently there is no present connection between core and corona.

XRD data (Fig. 8) shows that siderite is most abundant in fine-grained facies (4-6).

\section{Pyrite}

The occurrence of pyrite is universal throughout the formation, but it is generally found in very small amounts. Pyrite is most abundant in fine-grained samples which are also rich in organic matter. In sandstones, there is a positive correlation between pyrite and kaolinite, pyrite being insignificant in clean sandstones without authigenic kaolinite.

Pyrite is most commonly found as small framboids of 1-2 $\mu \mathrm{m}$ in size. These may form large clusters, eventually pseudomorphing organic matter. It may also occur as small porefilling clusters consisting of individual euhedral crystals.

In a single sample, pyrite is noted in relation to anhydrite (Plate $2, \mathrm{H})$. The pyrite is preserved as large ce-

\begin{tabular}{|c|c|c|c|c|c|}
\hline Well & Depth & $\mathrm{CaCO}_{3}$ & $\mathrm{MgCO}_{3}$ & $\mathrm{FeCO}_{3}$ & $\mathrm{MnCO}_{3}$ \\
\hline $\begin{array}{l}\text { Vedsted } 1 \\
\quad \text { interior (2) }\end{array}$ & $2010.35 \mathrm{~m}$ & & & & \\
\hline $\begin{array}{l}\text { interior (2) } \\
\text { margin (1) }\end{array}$ & & 57.5 & 21.7 & 18.3 & 2.5 \\
\hline $\operatorname{margin}(1)$ & & 56.0 & 19.8 & 21.4 & 2.9 \\
\hline Fjerritslev 2 & $2304.00 \mathrm{~m}$ & & & & \\
\hline interior (3) & & 49.6 & 29.3 & 18.4 & 2.7 \\
\hline margin (1) & & 50.0 & 25.4 & 22.0 & 2.6 \\
\hline Farsø 1 & $2874.00 \mathrm{~m}$ & & & & \\
\hline interior (1) & & 54.6 & 26.6 & 17.2 & 1.6 \\
\hline $\operatorname{margin}(1)$ & & 53.1 & 21.7 & 21.8 & 3.3 \\
\hline Aars $1 \mathrm{~A}$ & $3351.72 \mathrm{~m}$ & & & & \\
\hline interior (8) & & 54.7 & 28.6 & 14.4 & 2.4 \\
\hline margin (4) & & 52.0 & 24.8 & 20.9 & 2.4 \\
\hline
\end{tabular}

Table 1.

Microprobe analyses of Ankerite. Composition given as mole $\% \mathrm{CaCO}_{3}, \mathrm{MgCO}_{3}, \mathrm{FeCO}_{3}$ and $\mathrm{MnCO}_{3}$. (x) $=$ number of analyses. 

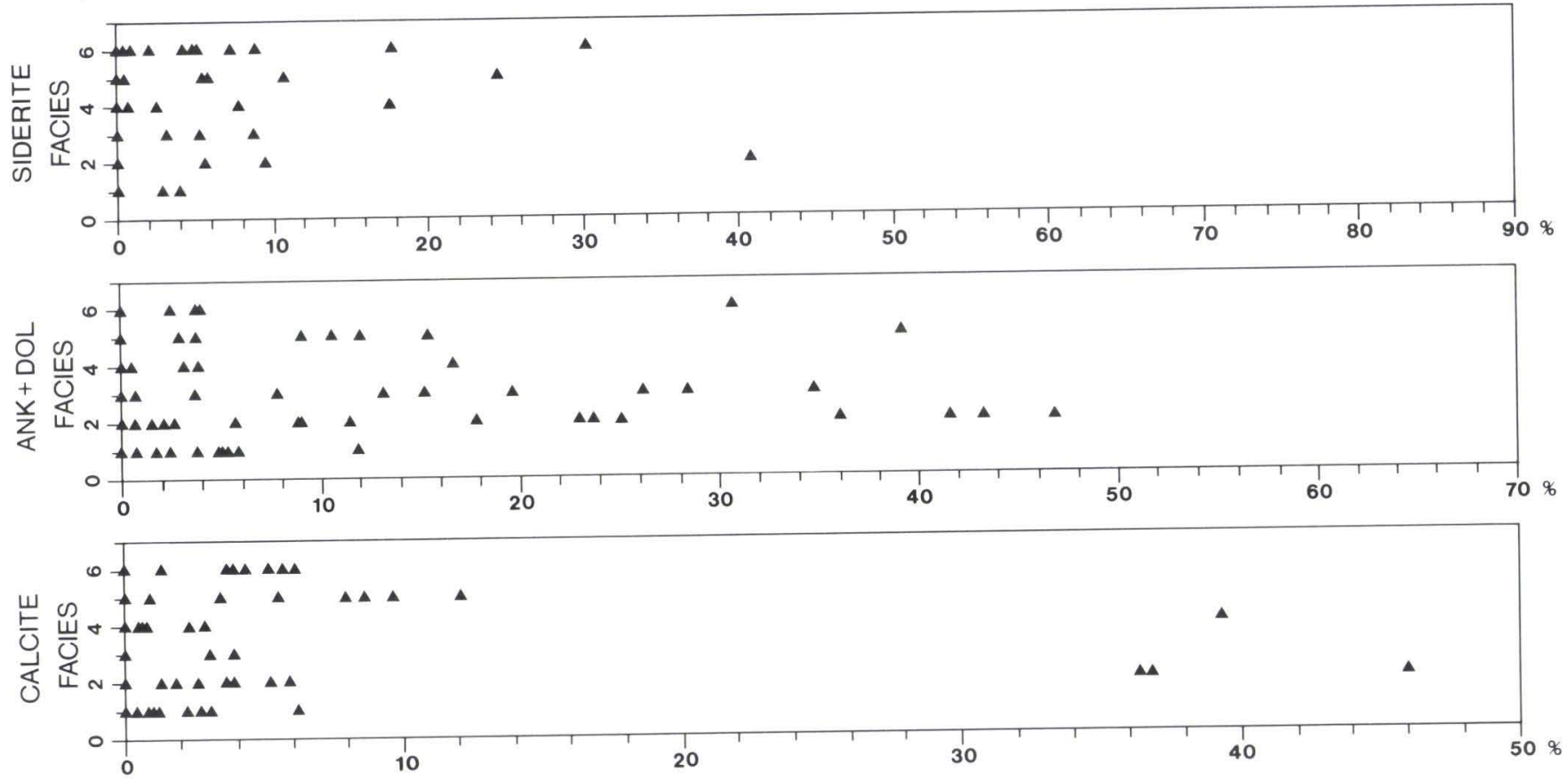

Fig. 8. Distribution of calcite, ankeriteldolomite and siderite in relation to lithology. Based on XRD-data, peak area-\%, bulk samples.

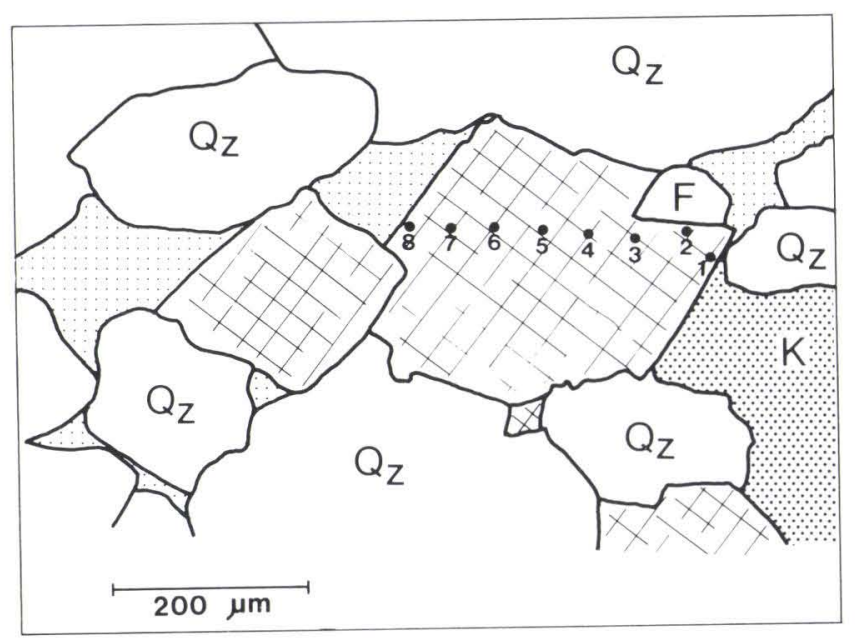

Fig. 9. Electron microprobe analyses of ankerite, sampling profile. Analytical data in Table 2. Aars 1 A, $3351.72 \mathrm{~m}$.

menting crystals within the anhydrite-cemented field, but not outside this field. This could indicate that pyrite was originally more common and was later partly dissolved.

Pyrite is observed to form the central part of spherolitic siderite (Plate 4,F) and also occur as scattered crystals within the siderite.

Pyrite is not seen replacing framework grains. In the Thisted 3 well, where extensive kaolinite replacement of feldspar has been noted, pyrite lines some of the original framework grains, demonstrating that the pyrite formed prior to kaolinite replacement.

EDX analyses have shown that some pyrite contain
$\mathrm{Cu}$. Pure pyrite and pyrite with $\mathrm{Cu}$-substitution may occur in the same sample.

\section{Kaolinite}

Kaolinite occurs abundantly in the sandstones of the Gassum Formation, and the textural relations indicate that the kaolinite is authigenic. The identification of kaolinite is based on thin section, SEM and XRD data. XRD of separated clay fractions (less than $2 \mu \mathrm{m}$ ) of the sandstones demonstrate the presence of well crystallized kandite (Fig. 10). The reflections are distinctly separated from chlorite reflections. The kandite is not totally destroyed by heating to $500^{\circ} \mathrm{C}$. After heating to $600^{\circ}$ for one hour, distinct reflections remain at $7 \AA$ and $3.5 \AA$, and only after heating to $600^{\circ}$ for three hours is the kandite totally destroyed. The high stability might indicate the presence of a high-order kandite such as dickite (Kantorowicz,1984,1985), but the X-ray diffractograms demonstrate no high-order reflections indicative of dickite or nacrite. The kandite is therefore referred to as a thermally stable kaolinite. The kaolinite occurs as both a porefilling and replacive phase.

Kaolinite is seen as porefilling cement in all levels of the formation and may constitute up to $8 \%$ by volume of individual samples. The porefilling kaolinite is generally well crystallized and occurs as hexagonal plates arranged in booklets or accordions. The size of the crystals range between 5 and $40 \mu \mathrm{m}$ and is generally uniform within each sample. However, the occurrence is patchy and random, also on a sample scale. Appar- 
ently there is no predictable relation between the occurrence of porefilling kaolinite and feldspar. Generally single pores are filled entirely while neighbouring pores may be empty. The porefilling kaolinite is itself highly porous, but the intercrystalline pores are very small (Plate 2,D; Plate 3,D). However, the open texture of the porefilling kaolinite allows a later formation of overgrowths of quartz and feldspar. These minerals grow almost freely into the intercrystalline porosity and engulf the kaolinite crystals (Plate 2,A,B; Plate $3, \mathrm{D}, \mathrm{E})$. The textural relations of kaolinite, quartz and feldspar clearly demonstrate that the kaolinite is porefilling and not replacive. Although the kaolinite may appear to replace quartz when studied by SEM (Plate $3, \mathrm{G})$, it is obvious from thin sections that the kaolinite crystals only occur in quartz and feldspar overgrowths and never in detrital cores (Plate $2 \mathrm{~A}, \mathrm{~B}$ ). In some cases, the formation of overgrowths on quartz and feldspar grains is locally retarded by the presence of kaolinite: Plate 2,D shows feldspar overgrowth only occurring on those parts of the feldspar not covered by kaolinite. The formation of kaolinite was obviously followed by quartz growth (Plate $2, \mathrm{~A}$ ), but it is not clear whether quartz also precipitated prior to kaolinite formation. In many cases, the porefilling kaolinite does not fill the entire original pore space, which could have been reduced in size by quartz growth before the precipitation of kaolinite took place (Plate 2,A). The relation between the porefilling kaolinite and partly dissolved feldspar grains is a little ambiguous. In most cases, the porefilling kaolinite lines original feldspar grain surfaces and does not enter the secondary porosity created by partial feldspar dissolution (Plate 2,C), although an outer rim may by partly invaded (Plate $2, E)$. However, in a few cases, the kaolinite fills both primary and secondary porosity.

In some parts of the formation kaolinite replacement of framework grains is common. In general, the replacement is complete and the nature of the original framework grain is not known. In some cases, however, remnants of the original grains are preserved, and

\begin{tabular}{lcccc}
\hline & $\mathrm{CaCO}_{3}$ & $\mathrm{MgCO}_{3}$ & $\mathrm{FeCO}_{3}$ & $\mathrm{MnCO}_{3}$ \\
\hline 1 & 53.3 & 24.2 & 20.5 & 2.0 \\
2 & 54.7 & 27.4 & 15.7 & 2.3 \\
3 & 55.1 & 29.2 & 13.4 & 2.2 \\
4 & 54.9 & 28.4 & 14.3 & 2.4 \\
5 & 55.3 & 27.4 & 14.7 & 2.6 \\
6 & 55.9 & 26.7 & 14.9 & 2.5 \\
7 & 54.9 & 28.6 & 14.2 & 2.4 \\
8 & 53.5 & 25.0 & 19.5 & 2.0 \\
\hline
\end{tabular}

Table 2.

Microprobe analyses of ankerite crystal in Figure 9 (Aars 1A, $3351.72 \mathrm{~m}$ ). Composition given as mole $\% \mathrm{CaCO}_{3}, \mathrm{MgCO}_{3}, \mathrm{FeCO}_{3}$ and $\mathrm{MnCO}_{3}$. Numbers refer to position (cf. Fig. 9). the relict grain is always a feldspar. In a single case kaolinite has replaced only the detrital feldspar, leaving a feldspar overgrowth intact. The replacive kaolinite may be strictly confined to the original framework grain (Plate 2,F), or it may occupy both grain position and surrounding pore-space to give the impression of oversize pores (Plate 2,E). Within the same sample there may be large differences between crystal size and amount of intercrystalline porosity of the kaolinite in individual replaced grains. This is probably caused by differences between the involved framework feldspars, but as no feldspar is left in these grains, the subject cannot be further clarified. In general, the replacive kaolinite can be distinguished from related porefilling kaolinite cement by differences in crystal size and density. This may indicate that the porefilling kaolinite and the replacive kaolinite were formed at different times or by different mechanisms. In most cases, the shape of the original grains is well preserved (when allowing for slight compactional deformation). This indicates that the replacement by kaolinite occurred after the main compactional event. The relation between replacive kaolinite and feldspar dissolution is not well known. In some cases, one of two neighbouring grains may be completely replaced by kaolinite while the other feldspar has been partly dissolved with no kaolinite formation in the secondary porosity. The most important occurrence of replacive kaolinite is seen in thin sandy intercalations in silt- and mudstone intervals in the Thisted 3 well. These levels are also strongly cemented by kaolinite (Plate 2,F)

\section{Chlorite}

Chlorite is locally very important as a porelining and partly porefilling cement as also described by Schmidt (1985b).

Neither the petrographic nor SEM appearance of the mineral seems typical for chlorite when comparison is made to published descriptions of authigenic chlorite (Wilson \& Pittman, 1977). However, XRD of the minus $2 \mu \mathrm{m}$ fraction separated from sandstones demonstrate the presence of chlorite. The chlorite (002) and (004) reflections are generally clearly separated from the kaolinite (001) and (002) reflections (Fig. 10), but the separation may be obliterated when one pair of reflections is much larger than the other. In the X-ray diffractograms, there is a distinctly elevated base line between the $10 \AA$ and the $14 \AA$ peaks. This may indicate the presence of mixed-layer clay minerals. The $10 \AA-14 \AA$ reflection pattern is not affected by treatment by ethylene glycol vapor, and it is inferred that the mixed-layer mineral is a disordered illite-chlorite complex.

In thin section, some chlorite is identified as detrital mica, but is generally somewhat altered. It is therefore 
inferred that the well-crystallized chlorite identified by $\mathrm{XRD}$ is the porelining clay noted in thin sections (Plate 4,A,B,C) and SEM (Plate 3,A,B,C,D).

The porelining chlorite occurs in varying thicknesses up to $10 \mu \mathrm{m}$, and in some cases it may also fill entire pores. Because of the distinct radial fabric (Plate 4,A), the uniform size distribution of individual particles (Plate 3,B) and its well crystallized character (Fig. 10), it is concluded that the porelining chlorite is authigenic.

The chlorite has a strong influence on later quartz cement. It is sufficiently dense to prevent the formation of quartz overgrowths on covered surfaces; the amount of quartz cement is distinctly lower in samples with thick pore-lining chlorite, and authigenic quartz may be virtually absent. Thus, the presence of chlorite linings is important for preservation of porosity, as also described by Pittman and Lumsden (1968). Where quartz cement occurs, the quartz growth is initiated on partly clean surfaces and spreads gradually over covered parts (Plate 3,A), as also described by Heald and Larese (1974). This relation clearly demonstrates that the quartz cement is younger than the pore-lining chlorite. The chlorite is apparently one of the first cementing phases. It covers pyrite, but is itself covered by authigenic kaolinite, quartz, feldspar and ankerite (plate $3, \mathrm{~A}, \mathrm{G})$.

In some cases, the pore linings have been distorted by compaction. Thus, the linings may be crumbled into the pores and parts of the framework grains are left uncovered. These portions of the grains may form the nuclei for later quartz overgrowths (Plate 4,C).

In Fars $\varnothing 1$ and Aars 1A, samples with abundant porelining chlorite (and consequently very little quartz cement), have abundant sutured contacts between quartz grains (Plate 4,B) indicating that pressure solution was important in these samples. Chlorite linings may be present within the sutured contacts, but in most cases the chlorite is apparently also dissolved along pressured contacts. The development of pressure solution is probably caused by the presence of pore-lining chlorite, partly because the chlorite prevented an early quartz cementation which might have stabilized the framework of the sediment (Heald and Larese, 1974), and partly because the chlorite may have acted as a catalyzing clay film (Heald, 1956; Thomson, 1959).

\section{Illite}

In samples from a depth of more than $2000 \mathrm{~m}$, a hairy or brushlike authigenic mineral occurs sporadically (Plate 3, E, F and H). Based on the appearance of the mineral it is assumed to be illite (Wilson \& Pittman, 1977; Güven et al. 1980). It occurs in primary porosity and is partly pore-lining. Plate 4,E shows that illite precipitated in remnant porosity after precipitation of kaolinite. Quartz overgrowths partly include the fine hairs of the illite (Plate 3, F,H).

\section{Anatase}

Anatase is recorded sporadically as small euhedral crystals up to $40 \mu \mathrm{m}$ in size. The composition has been proven by microprobe analyses. When present, the crystals cluster in primary pore space, and there is no evidence of precursor minerals. Anatase has not been documented by XRD, but some samples give a distinct reflection at $3.51 \AA$, which might represent anatase. Volumetrically, the authigenic anatase is unimportant.

\section{Anhydrite}

Anhydrite is recorded in one sample from the Gassum 1 well, where it occurs as one large poikilotopic crystal (Plate 2,H). The anhydrite occurs as cement, and there is no evidence of replacement. The texture of the ce-

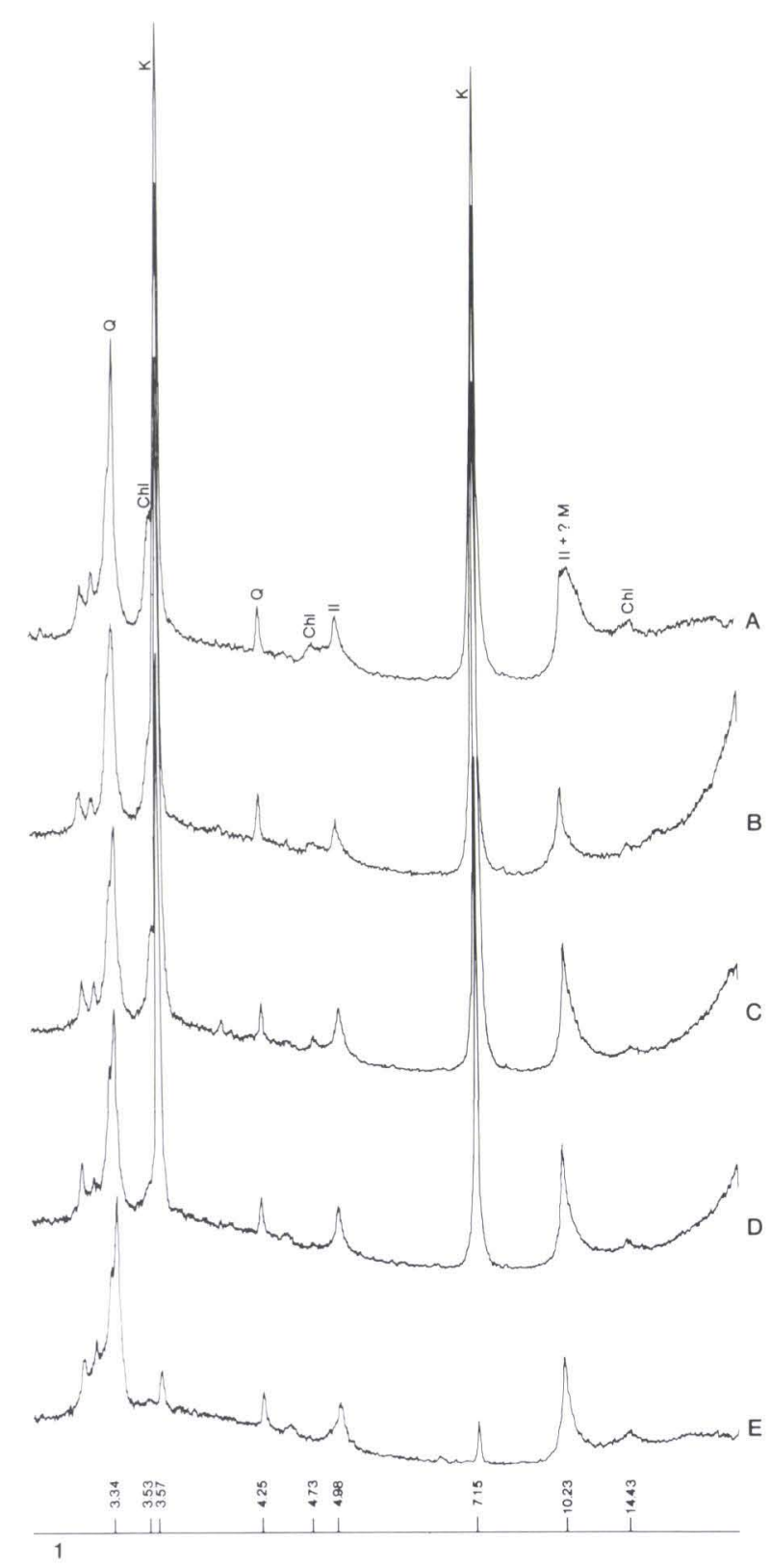


mented part is identical to that of the uncemented part with only slight compaction and quartz-cementation (Plate 4,F). Pyrite is abundant within the cemented part, whereas it occurs sparsely outside. Some framework grains, especially feldspar, may be partly dissolved, also when enveloped in pyrite.

\section{Porosity}

The point-counted porosity varies between $35 \%$ and $1 \%$. These values are generally lower than measured values (Priisholm \& Christensen, 1985), probably because microporosity has been understimated in point counts.

Fig. 10. X-ray diffractograms of typical clay fractions from sandstones. A: Mg-saturated sample, B: ethylene glycollated sample, $C$ : heated $300^{\circ} \mathrm{C}, 1$ hour, D: heated $500^{\circ} \mathrm{C}, 1$ hour, E: heated $600^{\circ} \mathrm{C}, 1$ hour, $\mathrm{F}$ : treated with $10 \% \mathrm{HCl}, 80^{\circ} \mathrm{C}$. Chl=Chlorite, $I l=$ illite, $? M=$ ?mixed-layer clay minerals, $K=$ kaolinite, $Q=$ quartz. $I=$ Aars 1 A, $3357.72 \mathrm{~m}, 2=$ Aars $I$ $A, 3215,85 \mathrm{~m}, 3=$ Fars $\emptyset 1,2892.56 \mathrm{~m}$.

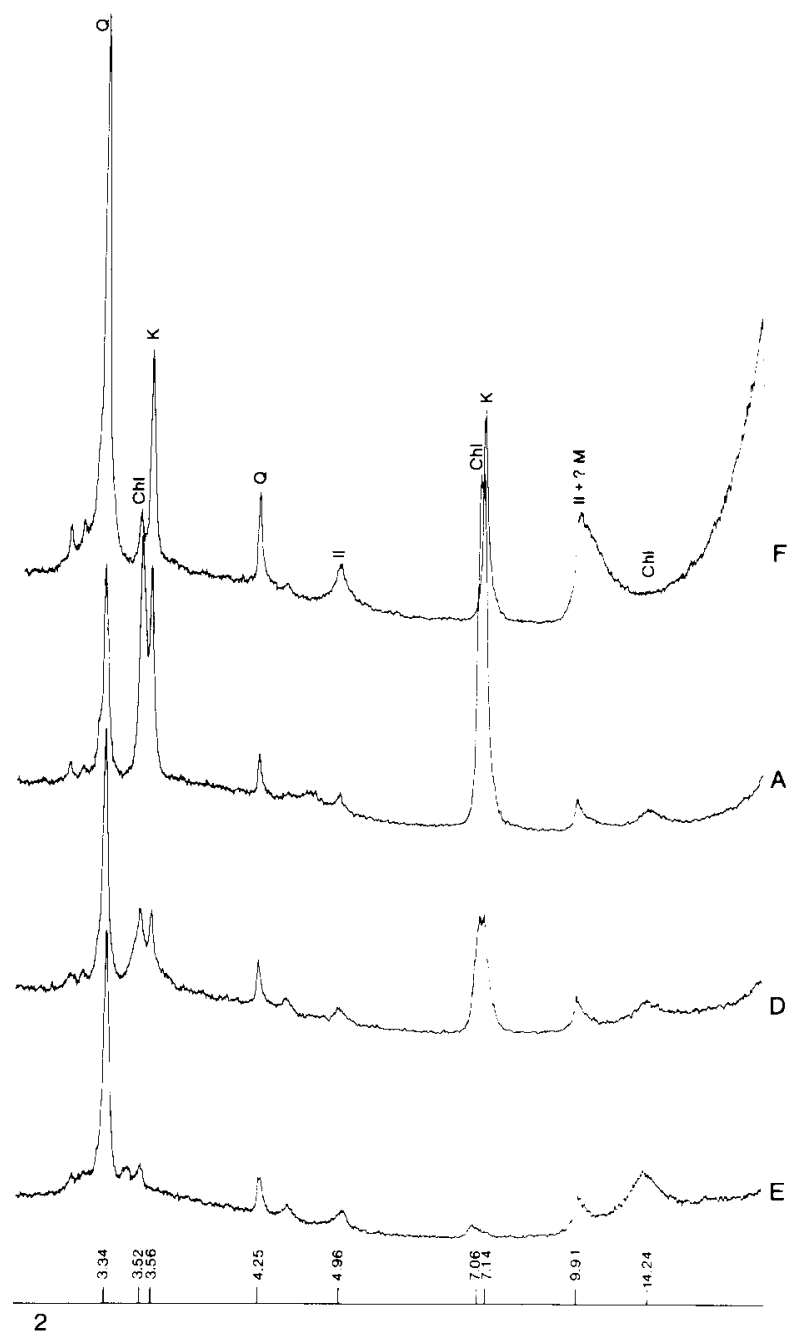

The variation in porosity is mainly related to depth (as also shown by Priisholm and Christensen, 1985), but the general decrease with depth may be overprinted by distribution of carbonate cement. In shallow samples, the porosity is mainly primary intergranular pore space, but secondary porosity after feldspar dissolution becomes increasingly important in depths from $1200-1500 \mathrm{~m}$. The secondary porosity is mainly distributed inside skeletal feldspar remnants and may occur as microporosity. At depths below $2000 \mathrm{~m}$ porosity is strongly reduced, mainly due to quartz cementation. In extreme cases, porosity is only present as microscopic residual primary porosity in intercrystalline positions in kaolinite cement or as secondary porosity in intracrystalline positions in partly dissolved feldspar.

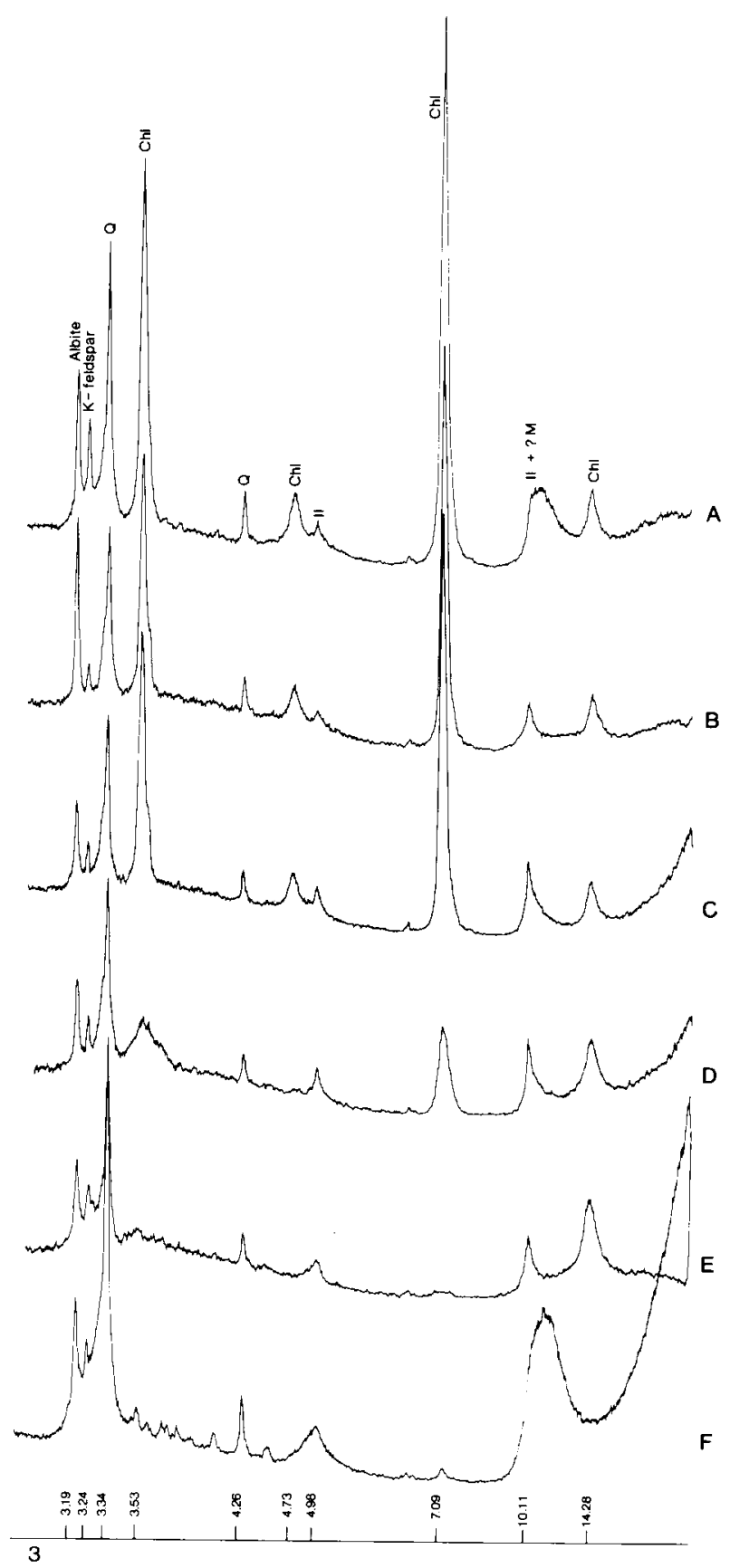




\section{Discussion}

\section{Diagenetic sequence}

Figure 11 shows the inferred relation between the most important diagenetic events. The earliest processes registered are formation of pyrite and siderite. In some samples, the occurrence of pyrite is closely related to the occurrence of kaolinite, but they were clearly not formed simultaneously. This is illustrated by the relations between pyrite, chlorite and kaolinite. In samples with porelining chlorite, pyrite is seen to occur as small framboidal aggregates between detrital grains and their porelining. This demonstrates, that the pyrite is older than the chlorite. On the other hand, porefilling kaolinite has formed within remnant pore-space after the formation of chlorite. In the samples from Thisted 3, where intensive replacement of detrital feldspar by kaolinite has taken place, pyrite may occur at the former grain surface between replacive kaolinite and porefilling kaolinite cement. On the basis of differences in crystal size and intercrystalline porosity in replacive and cementing kaolinite it can be inferred that the two kaolinite phases were formed at different times. As the pyrite is lining the former surface of the grain it must have been precipitated before the cementing kaolinite. However, the framework grains which are replaced by kaolinite are only slightly compacted, and this relation points to a post-compactional replacement. Therefore, it is most likely that the pyrite formed before the replacing kaolinite, but this suggestion is uncertain.

The occurrence of pure pyrite and pyrite with $\mathrm{Cu}$ substitution in the same samples may indicate that the formation of pyrite took place in at least two separate phases, but the textural relations of the two different pyrites could not be distinguished.

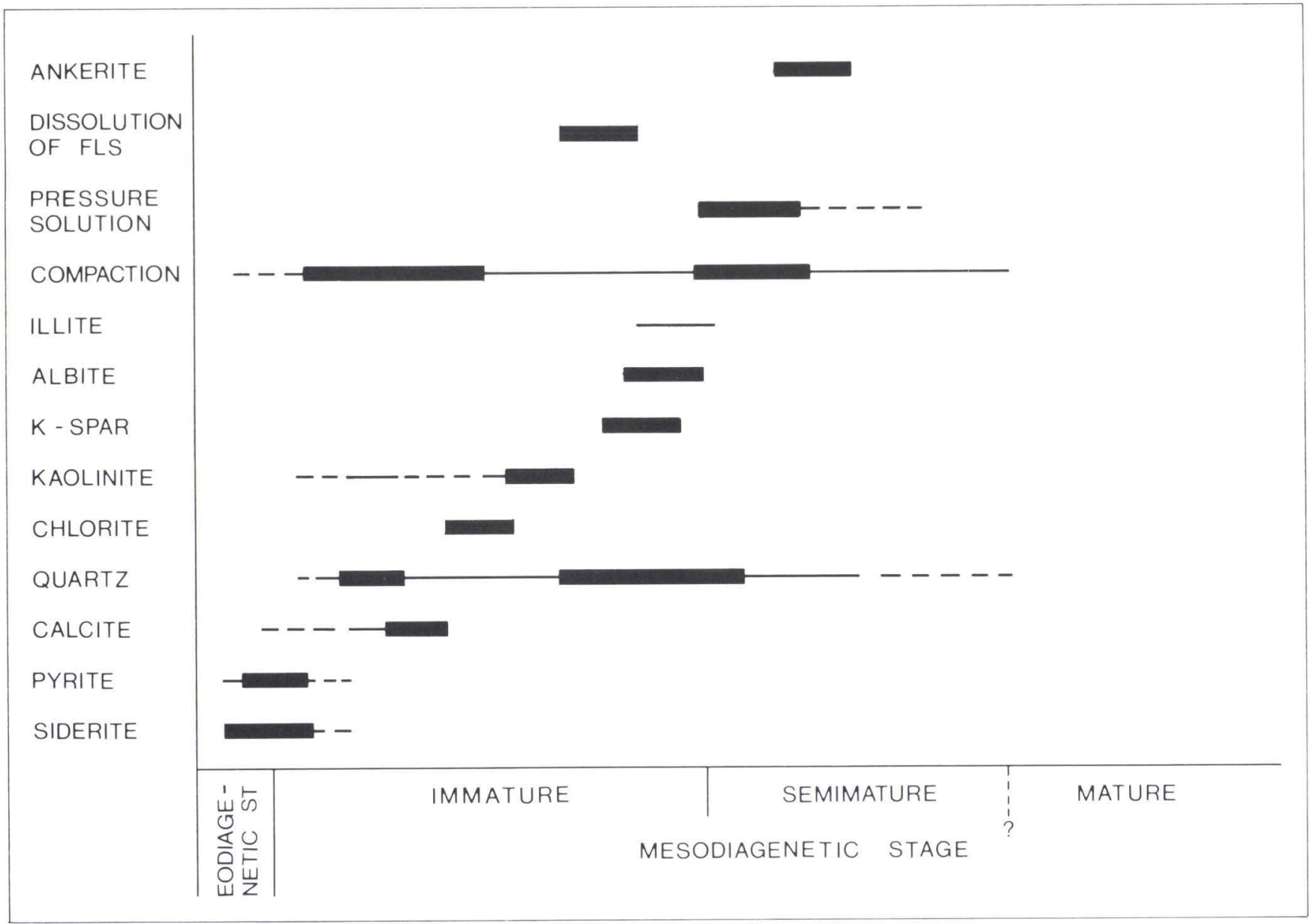

Fig. 11. Diagenetic sequence, Gassum Formation. 
The relation between pyrite and siderite cannot be observed, and it is uncertain which of them formed first, although they occur together in some samples. In some cases, siderite occurs inside expanded mica, probably biotite (Plate $4, F$ ). This occurrence is clearly related to the breakdown of the mica, which must have been depleted in iron. The incorporation of the released Fe into siderite demonstrates that the process took place under reducing conditions, and that the activity of sulphide ions was low. This could reflect a low salinity pore fluid, as would be expected in deltaic sediments, but the depositional environment is not sufficiently well established to support hypotheses on original pore fluid composition.

Siderite crystals may be zoned on a microscopic scale. The core is darkly reddish and consists of almost pure siderite, with only minor substitution by $\mathrm{Ca}$. The outher rim has a composition close to ankerite (Yde, 1983), but XRD-data only demonstrate the presence of siderite. The low Fe-content in these siderites indicate a lower Fe-activity, either because the supply of iron was generally too low, or because the Fe was consumed by sulphide. This may indicate the intrusion of sea water in the formation with a surplus of $\mathrm{SO}_{4}, \mathrm{Ca}, \mathrm{Mg}$, and $\mathrm{Mn}$. It is therefore possible that siderite started to precipitate earlier than pyrite and continued its growth with a different composition after pyrite started to precipitate.

The initial compaction of the sediment was largely completed before any important cementation took place. Porelining chlorite is one of the earliest cements and clearly predates kaolinite, quartz and authigenic feldspar. Furthermore, it is generally undisturbed by early compaction. The linings have not been ruptured by reorganization of the framework grains and thus inhibited the formation of quartz overgrowths.

There is also evidence of early quartz cementation. Apparently this slight cementation occurred before the formation of kaolinite, as in some cases the porefilling kaolinite does not fill the entire primary pore space but seems to have precipitated on preexisting quartz overgrowths (Plate 2,A). The relation between the porelining chlorite and incipient quartz cementation could not be established.

The formation of calcite cement occurred after incipient quartz cement and after early compaction, but the relation between calcite and other authigenic phases is not well established.

The main phase of quartz cementation, which is only noted in samples from depths greater than $1500 \mathrm{~m}$, occurred after the formation of kaolinite. Apparently, the formation of authigenic potassium feldspar and albite occurred contemporaneously with quartz cementation. There is no direct evidence as to which of the authigenic feldspars formed first. Alkali feldspar is the only authigenic feldspar found at the shallower depths and probably formed earlier in the deep wells also.
Feldspar dissolution is an important phenomenon at all present depths of burial. It was initiated after the main phase of compaction had already occurred, but is evident in all present depths of burial. Obviously, the feldspar dissolution is post-compactional. Most feldspar dissolution was selective and left fragile skeletons. Similar skeletal feldspars have also been observed by Sicbert et al. (1984) who also concluded a postcompactional feldspar dissolution. Similarly, well preserved chlorite molds after partly dissolved feldspar grains point to a postcompactional dissolution (also shown by Siebert et al., 1984). In most cases, the dissolution also occurred after the precipitation of kaolinite, as the pore-filling kaolinite does not enter the secondary porosity created by feldspar dissolution. Siebert et al. (1984) observed a similar restriction on kaolinite distribution and also concluded that kaolinite formed prior to feldspar dissolution.

In addition, there is evidence for some kaolinite formation after feldspar dissolution, with kaolinite crystals precipitated in the marginal areas of partly dissolved feldspar or filling oversize pores after feldspar.

The formation of authigenic illite cannot be related to other diagenetic phases with certainty. It may be older than quartz as seen from Plates $3, E, F$ and $H$. It may be related to albitization or dissolution of potassium feldspar with depth.

Pressure solution and further compaction occurred after the main cementation by quartz as only slightly cemented samples have pressolved contacts. The pressure solution is followed by slight quartz cementation.

Ankerite cement is the last cement and replaces all other components. Calcite may have been more universally present as it occurs at greater depths in the finegrained facies than in the coarser facies (Fig. 6). However, there are no distinct textural indications of calcite dissolution in the sandstones. Boles (1978) suggested a calcite replacement by ankerite based on chemical composition of the ankerite. The composition of Gassum Formation ankerites (Table 1 and 2) does not indicate a replacement origin of the ankerite.

The time of formation of the anhydrite cement cannot be well specified because of its sparse distribution. It is notable that the part of the sandstone which was cemented by anhydrite has a similar texture to the uncemented part of the sandstone; the main compaction clearly occurred before precipitation of anhydrite. Further, the amount of quartz cement is the same in both uncemented and cemented parts, indicating that formation of quartz preceeded the formation of anhydrite. Secondary porosity after partial dissolution of feldspar is also noted inside the anhydrite crystal. This might indicate that the anhydrite is younger than feldspar dissolution, but this is partly contradicted by the fact that the intragranular porosity in feldspars has not been filled by anhydrite. 


\section{Pressure solution}

The role of pressure solution in sandstone diagenesis has been discussed intensively by Heald (1959), Ernst and Blatt (1964), Renton, Heald and Cecil (1969), de Boer (1977a,b), de Boer, Nagtegaal and Duyvis (1977) and many others. It is an important mechanism for porosity reduction at depth (the semimature and mature stages of mesodiagenesis (Schmidt and McDonald, 1979). According to de Boer et al. (1977) the development of pressure solution indicates a slow rate of pressure build-up. A rapid rate of pressure build-up results in grain breakage rather than pressure solution, but it is unclear what "slow" and "rapid" mean in terms of geologic time. Ernst and Blatt (1964) relate pressure solution to conditions where porefluid pressure is less than the lithostatic pressure. Combined mechanical compaction and chemical compaction was reported from Jurassic sandstones from the Danish Subbasin by Nielsen \& Friis (1985). A prerequisite for pressure solution to take place is the presence of reduceable porosity. Various mechanisms may be responsible for the preservation of open porosity, either lack of cement or dissolution of early cement or framework grains. Füchtbauer (1974b) suggested, that because of the very low solubility of silica, reprecipitation of silica would occur simultaneously with pressure solution of quartz. This is not always the case (Nielsen and Friis, 1985).

Within the Gassum Formation there is a steady decline of porosity with depth, mainly due to pervasive quartz cementation, but also because of intensive ankerite cementation in the deepest parts of the formation. However, quartz was formed prior to ankerite cement as demonstrated by the textural relations (Plate $4, \mathrm{H})$ and the pressure solution was controlled by presence/absence of quartz cement rather than ankerite cement, which was introduced at a later time. The porosity was primarily kept open by local thick chlorite coatings on framework grains. This mechanism is widely recognized (Pittman \& Lumsden, 1968; Pittman, 1972; Heald \& Larese, 1974). Where slight compaction occurred after the formation of pore-lining chlorite, the linings were dislodged, and quartz precipitated on the exposed surfaces of detrital quartz grains. This also stabilized the sediment, and pressure solution is uncommon. Where chlorite linings are well preserved, quartz cementation was strongly retarded. Consequently, the porosity remained open until conditions were favourable for pressure solution to evolve. This defines the onset of the semimature stage of the mesodiagenesis (Schmidt and McDonald, 1979), but can only be recognized when open porosity is still left. Pressure solution results in a considerable reduction in pore space as shown by Mitra and Beard (1980).

The pore-lining chlorite may become thin or disappear in the central part of the pressured contacts (Plate $4, \mathrm{~A})$. The chlorite is probably also dissolved together with quartz. The role of clay in pressure solution has been discussed by Heald (1956) and Thomson (1959), who concluded, on the basis of an observed correlation between clay and pressure solution or sandstone stylolites, that the clay promoted dissolution of quartz. They also found that the composition of the clay was changed during the process. The direct role of clay mentioned by Thomson (1959) may also have been important in the Gassum Formation, but it seems more important that the clay prevented the formation of quartz overgrowths, and thus kept a large volume of reduceable porosity open until conditions for the semimature stage of mesodiagenesis were reached.

The effect of pressure solution has been to further compact the sandstone. During this compaction, the protective clay linings were partly removed, exposing the detrital quartz grains to the pore fluid, forming overgrowths. The silica dissolved from quartz and chlorite reprecipitated as quartz overgrowths as suggested by Füchtbauer (1974), whereas the released magnesium and iron was probably incorporated into ankerite.

\section{Feldspar dissolution/precipitation}

The composition of the sandstones has been strongly modified by diagenesis, partly because of strong quartz cementation and partly because of intensive feldspar dissolution. Therefore the petrographic classification is of limited value but it may give some information on diagenesis. Figure 4 shows that the porous sandstones from the shallow wells are generally more immature than the well-cemented sandstones from deep wells. This reflects an increasing quartz cementation with depth and a progressive dissolution of feldspar with depth.

On a sample scale, there does not seem to be a strict relation between feldspar composition and dissolution but on a large scale it appears that plagioclase was more soluble than alkali feldspar. In a few cases, detrital cores were preferentially dissolved, leaving a rim of undissolved authigenic feldspar.

The change in feldspar composition with depth follows only slight modification of the framework feldspar. This could indicate a solid state albitization of the grains. Albitization has been intensively discussed by several workers (Middleton, 1972; Ogunyomi et al., 1981; Boles, 1982, 1984; Walker, 1984; Helmold \& van de Kamp, 1984). Direct evidence of albitization has not been noted in Gassum Formation sandstones. On the other hand, skeletal remnants of feldspar have formed the nuclei for albite overgrowths, as also described by Boles (1982) and Bjørlykke (1984). These feldspar overgrowths may partly or completely fill the secondary intragranular porosity, but in most cases only very small overgrowths project outside the original grain 
outline. This imparts a strong resemblance to solid state albitization, but apparently the dissolution and precipitation were separate and unrelated processes. The restriction of authigenic albite to secondary porosity cannot be explained by observation.

Franke and Ghobarkar (1980, 1982) described the relation between temperature and crystal morphology in experimentally-produced hydrothermal albite and potassium feldspar. In the present material the morphology of individual crystallites is variable (Plate 1, $\mathrm{F}, \mathrm{H})$, and it does not seem possible to relate crystal morphology to specific conditions during formation.

Siebert et al. (1984) discussed the possibilities for feldspar dissolution at depth. They related the feldspar dissolution to the release of $\mathrm{CO}_{2}$ by maturation of organic matter. When comparison is made to maturation data by Thomsen et al. (1983) and Schmidt (1985a) it seems likely that at depths about $1500 \mathrm{~m}$ and deeper, carbon dioxide was produced by maturation of organic matter. According to Siebert et al. (1984) dissolution of feldspar may result in precipitation of carbonates, e.g. calcite. This could explain the strong replacement of feldspar by carbonates noted in many samples. However, the late precipitation of ankerite is probably not related to feldspar dissolution although feldspar may also be replaced by ankerite. This is seen from Plate 4, $\mathrm{H}$, where the ankerite crystal grows into already open intragranular porosity of a framework feldspar and Plate 4,G where authigenic albite has been replaced by ankerite.

In most cases there is no relation between dissolution of feldspar and precipitation of clay minerals. It is therefore assumed that feldspar dissolution occurred under conditions where aluminium and possibly also silica could be removed from the system, eventually to other parts of the sandstone. Based on laboratory experiments Surdam et al. (1984) showed that decomposition of organic matter produces carboxylic acids and that these acids may play an important role in feldspar decomposition and may complex with aluminium. In this way the aluminium may be carried out of the sandstone and eventually reprecipitate as kaolinite in other parts of the formation. Only in interlaminated sand and mud in the Thisted 3 well has it been noted that formation of kaolinite is directly related to the break-down of feldspar. This is probably the result of poor pore-fluid exchange, or it may result from feldspar decomposition caused by high concentrations of $\mathrm{CO}_{2}$ as described by Surdam et al. (1984) and Siebert et al. (1984). The process may be related to post-compactional cementation by calcite (Siebert et al., 1984; Surdam et al., 1984), but there is no supporting textural evidence. Because feldspar dissolution occurred prior to albitization, solvents must have transported ions in solution out of the sandstone. Therefore it is possible that the pore-fluid contained organic acids which were responsible for the feldspar dissolution and for transportation of the dis- solved aluminium (Surdam et al., 1984), and that the sandstone was open for water movements. At a later stage the albite was precipitated. This implies that sodium, aluminium and silica was carried into the system by moving pore-fluids from deeper parts of the formation. This may have resulted from a pervasive replacement by ankerite at depth, but this can not be further discussed due to lack of sample material from the deepest parts of the formation.

\section{Relation between facies and diagenesis}

The diagenetic evolution was to some degree controlled by lithology. This is best illustrated by the occurrence of carbonates, which are entirely authigenic in origin and therefore only reflect changes in the diagenetic pattern. Calcite and ankerite distributions are mainly controlled by depth of burial. Calcite is generally found at depths less than $2000 \mathrm{~m}$ and ankerite at depths below $2000 \mathrm{~m}$, but this is valid only for sandstones. In shales and siltstones calcite is also found in deeply buried samples (Fig. 8). This may indicate that the diagenetic reactions were strongly reduced in the most finegrained parts of the formation because of reduced permeability. Figure 8 also shows that ankerite is not abundant in the finegrained lithologies. This implies that diagenetic changes in the mudrock sequences of the formation took place rather early when sediments were still permeable, and that the diagenetic transformation gradually became slow. Early diagenetic minerals had a better preservation potential in these lithologies than in the better permeable sandstones where they in some cases were dissolved or replaced by others, e.g. ankerite. The same effect is shown by the occurrence of feldspar in different lithologies. In coarse grained sandstones, the amount of feldspar is drastically reduced with depth (Fig. 5), probably first due to dissolution of plagioclase but later also due to alkali feldspar. With deeper burial, the total content of feldspar gradually increases due to the precipitation of albite. In fine-grained lithologies, the content of feldspar is not variable with depth and plagioclase is more common than in coarse-grained lithologies. This may partly be a depositional property but may also indicate that the mudrocks were already sealed when feldspar diagenesis became important. Furthermore, partly dissolved or replaced feldspar grains in sandstones are never compressed by compaction, indicating that the main compaction occurred prior to feldspar dissolution: therefore, the mud-rock lithologies would also have been compacted and lost their permeability. Diagenetic isolation of the finegrained lithologies of the formation will have limited any contributions from the mudrocks for the sandstone diagenesis. It may therefore also be difficult to explain the large introduction of magnesium and iron into the sandstones 
for the late formation of ankerite. Boles (1978) suggested a clay mineral source for the replacement of calcite by ankerite. It is suggested that in the Gassum Formation sandstones and mudrocks reacted as two isolated systems and that the exchange of cations was limited. This implies that either internal sources within the sandstones were most important when diagenetic changes took place, or that the sandstones were flushed by formation fluids from external sources. The transformation of clay minerals would be an important source for cations and water. However, clay mineral analyses indicate that little change has taken place in the Gassum Formation mudrocks. Smectite is very rare at all sample depths, and the occurrence of smectite in the Mesozoic of the Danish Embayment may be related to stratigraphy rather than diagenetic evolution with depth (Schmidt, 1985b).

\section{Diagenetic evolution}

As demonstrated by Priisholm (1983) there is a steady decline in average porosity with depth. According to Priisholm and Christensen (1985) the expected porosity decreases from about $40 \%$ at surface conditions to about $8 \%$ at a depth of $3500 \mathrm{~m}$, decreasing $9 \%$ per 1000 $\mathrm{m}$. At depths of less than $1500 \mathrm{~m}$, cementation is generally insignificant, and the average porosity decrease with depth is partly explained by simple mechanical compaction in the immature stage of the mesodiagenesis as defined by Schmidt and McDonald (1979). There may be an important formation of secondary porosity also in these shallow parts of the formation, due to dissolution of detrital feldspar.

The geothermal gradient has been estimated by Michelsen et al. (1981) to be about $25^{\circ} \mathrm{C}$ per $1000 \mathrm{~m}$, which is comparable to the geothermal gradient used by Schmidt and McDonald (1979) in their concept of diagenetic regimes. Before the Late Cretaceous, the maximum burial depth was $1700 \mathrm{~m}$. Up to this point, therefore, it was likely that only mechanical compaction played a significant role in reduction of porosity (Schmidt \& McDonald, 1979). When rapid subsidence was initiated in the Late Cretaceous, the deepest parts of the formation reached the semimature stage of mesodiagenesis, where chemical compaction may reduce porosity further than was possible by simple mechanical compaction. At this stage the diagenesis followed two lines. There was a major phase of cementation by quartz and partly by albite, occurring mainly in clean sandstones with a resultant reduction in porosity to about 2 volume per cent. Primary porosity is totally reduced except for microscopic intercrystalline porosity in kaolinite porefilling cement. Secondary porosity is generally not reduced by compaction, but may be reduced by cementation. Some levels have been cemented by chlorite, probably during the immature stage of the mesodiagenesis, as further compaction has modified the pattern of distribution of the chlorite. The presence of porelining chlorite prevented quartz cementation and thus promoted pressure solution (chemical compaction) in the semimature stage of the mesodiagenetic stage. Even at a depth of $2800 \mathrm{~m}$, the primary porosity is still significant indicating that the mature stage of Schmidt and McDonald has not been reached.

The residence time in the semimature stage is about 80 million years (since the Late Cretaceous). Also compared with data suggested by Schmidt and McDonald (1979) it is reasonable to conclude that the mature stage has not been reached.

Within the Danish Subbasin there are marked differences in geothermal gradients, dependant on the position relative to salt domes (Madsen, 1978; Michelsen et al. 1981). This has also influenced maturation of organic matter (Thomsen et al. 1983; Schmidt, 1985 a) Of special interest is the Gassum 1 well, where the geothermal gradient is as high as $32^{\circ} \mathrm{C} / 1000 \mathrm{~m}$ (Madsen, 1978), and the vitrinite reflectance index increases $0.6 \% 1000 \mathrm{~m}$, more than three times the rate of wells from areas with the average geothermal gradient (Schmidt, 1985). However, the diagenetic mineral assemblages in Gassum 1 are not specifically influenced by the higher temperatures as compared with other wells. 


\section{Conclusion}

The diagenetic evolution of the Gassum Formation is mainly controlled by burial depth. Early diagenetic minerals, formed under eodiagenetic and early mesodiagenetic conditions are siderite and pyrite. Volumetrically important cementation only occurred after initial compaction had been completed, and except for late diagenetic pressure solution (chemical compaction) there is little evidence for compactional modification of the cementation pattern and reduction of secondary porosity.

The porosity gradually decreases with depth. Down to $1500 \mathrm{~m}$ the decrease is mainly due to simple compaction, and the porosity may be relatively increased by secondary porosity after feldspar dissolution. Deeper than $1500 \mathrm{~m}$ the porosity is reduced by pervasive cementation, mainly quartz, but also kaolinite, alkali feldspar, albite and ankerite. Chlorite cement is present in some samples. It formed as the first cement after compaction and prevented the formation of quartz overgrowths. This resulted in pressure solution when the depth of burial became sufficient or when fluid pressure was reduced.
The dissolution of feldspar occurred after precipitation of kaolinite, and was probably caused by the introduction of organic acids released by maturation of organic matter. It is suggested that the involved acids could complex aluminium as there is no indication of contemporaneous precipitation of clay minerals and feldspar.

The time difference between kaolinite precipitation and feldspar dissolution indicates that the formation was open to pore fluid movements. The kaolinite was probably formed by dewatering of deeper parts of the formation where feldspar dissolution by organic acids released during maturation of organic matter took place. After further subsidence, feldspar dissolution occurred where earlier kaolinite precipitated.

Later, after the main quartz cementation, water circulation was restricted, and overpressure may have prevented pressure solution until better circulation again lowered pore fluid pressure. 


\section{Acknowledgements}

The author is greatly indebted to Søren Priisholm and Olaf Michelsen, The Geological Survey, who invited him to participate in the project "Geothermal Reservoirs in Denmark". Palle Rubæk Andersen (The Geological Survey), Stanley Fine (The Geological Survey) and Bjarne Leth Nielsen (Dansk Olie- og Gasproduktion $\mathrm{A} / \mathrm{S}$ ) are thanked for valuable assistance and for inspiring cooperation and discussions. Sidsel Grundvig (University of Aarhus) is thanked for kind assistance with the microprobe. Andrew Morton (British Geological Survey, Nottingham), Henning Dypvik (University of Oslo), Bjarne Leth Nielsen, Nils Frandsen
(Dansk Olie- og Gasproduktion A/S) and Stanley Fine read the manuscript and gave valuable suggestions. Stanley Fine improved the English manuscript. The directors of the Geological Survey of Denmark and Dansk Olie- og Gasproduktion A/S are thanked for the permission to use confidential material. The study formed a part of the projects "Geothermal Reservoirs in Denmark" and EFP-83 "Diagenesis of Clastic Reservoir Rocks, Onshore Denmark", and has been partly financed by the E.E.C. and the Danish Ministry of Energy. Much of the equipment used has been financed by the Danish National Science Foundation. 


\section{References}

Bertelsen, F., 1978: The Upper Triassic - Lower Jurassic Vinding and Gassum Formations of the Norwegian-Danish Basin. Danmarks geol. Unders., Series B, 3, 26 pp.

Bertelsen, F., 1980: Lithostratigraphy and depositional history of the Danish Triassic. Danmarks geol. Unders., Series B, 4, 59 pp.

Bjørlykke, K., 1984: Formation of secondary porosity: how important is it? in: McDonald, D.A. \& R.C. Surdam (Eds): Clastic Diagenesis, A.A.P.G. Memoir 37, 277-286.

Boer, R.B. de, 1977a: On the thermodynamics of pressure solution interaction between chemical and mechanical forces. Geochim. Cosmochim. Acta, 41, 249-256.

Boer, R.B. de, 1977b: Pressure solution: theory and experiments. Tectonophysics, 39, 287-301.

Boer, R.B. de, Nagtegaal, P.J.C. \& Duyvis, E.M., 1977: Pressure solution experiments on quartz sand. Geochim. Cosmochim. Acta, $41,257-264$

Boles, J.R., 1978: Active ankerite cementation in the subsurface Eocene of southwest Texas. Contrib. Mineral. Petrol., 68, 13-22.

Boles, J.R., 1982: Active albitization of plagioclase, Gulf Coast Tertiary. Am. Journ. Sci., 282, 165-180.

Boles, J.R., 1984: Secondary porosity reactions in the Stevens Sandstone, San Joaquin Valley, California. in: McDonald, D.A. \& R.C. Surdam (Eds): Clastic Diagenesis. A.A.P.G. Memoir 37, 217-224.

Boles, J. R. \& Franks, S.G., 1979: Clay diagenesis in Wilcox Sandstones of Southwest Texas: implications of smectite diagenesis on sandstone cementation. Jour. Sedim. Petrol., 49, 55-70.

Ernst, W.G. \& Blatt, H., 1964: Experimental study of quartz overgrowths and synthetic quartzites. Jour. Geol., 72, 461-470.

Franke, W. \& Ghobarkar, H., 1980: Die Morphologie von Albit beim wachstum aus überkritischer Phase. Zeitschrift für Physikalische Chemie, N.F. 122, 43-51.

Franke, W. \& Ghobarkar, H., 1982: The morphology of hydrothermally grown K-feldspar. Neues Jahrbuch f. Mineralogie, Monatshefte, 1982, 57-68.

Friedman, G., 1971: Staining. In: Carver, R.E. (Ed.): Sedimentary Petrology. Wiley Interscience, 511-530.

Friis, H., 1985: Cementering af det cenomane fosforitkonglomerat under Arnager Grønsandet ved Madsegrav, Bornholm. Dansk geol. Foren., Årsskrift for 1984, 1-5.

Füchtbauer, H., 1974: Some problems of diagenesis in sandstones. Bull. Centre Rech. Pau, 8, 391-403.

Galloway, W.E., 1984: Hydrogeologic regimes of sandstone diagenesis. in: McDonald, D.A. \& R.C. Surdam (Eds): Clastic Diagenesis, A.A.P.G. Memoir 37, 3-13.

Güven, N., Hower, W.F. \& Davies, D.K., 1980: Nature of authigenic illites in sandstone reservoirs. Jour. Sedim. Petrol., 50, 761-766.

Heald, M.T., 1956: Cementation of Simpson and St Peter Sandstones in parts of Arkansas and Missouri. Jour. Geol., 64, 16-30.

Heald, M.T., 1959: Significance of stylolites in permeable sandstones. Jour. Sedim. Petrol., 29, 251-253.

Heald, M.T. \& Larese, R.E., 1974: Influence of coatings on quartz cementation. Jour. Sedim. Petrol., 44, 1269-1274.

Helmold, K.P. \& van de Kamp, P.C., 1984: Diagenetic mineralogy and controls on albitization and laumontite formation in Paleogene arkoses, Santa Ynez Mountains, California. in: McDonald, D.A \& R.C. Surdam (Eds): Clastic Diagenesis, A.A.P.G. Memoir 37 , 239-276.

Kantorowicz, J., 1984: The nature, origin and distribution of authigenic clay minerals from Middle Jurassic Ravenscar and Brent Group sandstones. Clay minerals, 19, 359-375.
Kantorowicz, J.D., 1985: The petrology and diagenesis of Middle Jurassic clastic sediments, Ravenscar Group, Yorkshire, Sedimentology, 32, 833-853.

Larsen, F., Nilsen, L.H. \& Frandsen, N., 1987: Depositional environment of the Upper Triassic-Lower Jurassic Gassum Formation, Sjalland, Denmark. Danmarks geol. Unders., in prep.

Larsen, G., 1966: Rhaetic-Jurassic-Lower Cretaceous sediments in the Danish Embayment (a heavy mineral study). Danmarks geol. Unders., rakke 2, 91, $128 \mathrm{pp}$.

Longstaffe, F.J., 1984: The role of meteoric water in diagenesis of shallow sandstones: stable isotope studies of the Milk River aquifer and gas pool, southeastern Alberta. in: McDonald, D.A. \& R.C Surdam (Eds): Clastic Diagenesis, A.A.P.G. Memoir 37, 81-98.

Longstaffe, F.J., 1986: Oxygen isotope studies of diagenesis in the basal Belly River Sandstone, Pembina I-Pool, Alberta. Jour. Sedim. Petrol., 56, 78-88.

Loucks, R.G., Dodge, M.M. \& Galloway, W.E., 1984: Regional controls on diagenesis and reservoir quality in lower Tertiary sandstones along the the Texas Gulf Coast. in: McDonald, D.A. \& R.C. Surdam (Eds): Clastic Diagenesis, A.A.P.G. Memoir 37, 15-45.

Madirazza, I., 1975: The geology of the Vejrum salt structure. Bull. geol. Soc. Denmark, 24, 161-171.

Madsen, L., 1978: Geotermisk energi i Danmark - en geologisk vurdering. Dansk geol. Foren., Årsskrift for 1977, 29-40.

Michelsen, O., 1975: Lower Jurassic biostratigraphy and ostracods of the Danish Embayment. Danmarks geol. Unders., series 2, 104, $287 \mathrm{pp}, 42$ plates.

Michelsen, O., 1978: Stratigraphy and distribution of Jurassic deposits of the Norwegian-Danish Basin. Danmarks geol. Unders., Series $\mathrm{B}, 2,28 \mathrm{pp}$.

Michelsen, O. \& Bertelsen, F., 1979: Geotermiske reservoirformationer i den danske lagserie. Danmarks geol. Unders., Årbog 1978, 151-163. With an English abstract.

Michelsen, O., Saxov, S., Leth, J.A., Andersen, C., Balling, N., Breiner, N., Holm, L., Jensen, K., Kristiansen, J.I., Laier, T., Nygaard, E., Olsen, J.C., Poulsen, K.D., Priisholm, S., Raade, T.B., Sørensen, T.R. \& Wurtz, J., 1981: Kortlægning af potentielle geotermiske reservoirer i Danmark. Danmarks geol. Unders., Series B, 5, $96 \mathrm{pp}$. with an English summary.

Middleton, G.V., 1972: Albite of secondary origin in Charny Sandstones, Quebec. Jour. Sedim. Petrol., 42, 341-349.

Mitra, S. \& Beard, W.C., 1980: Theoretical models of porosity reduction by pressure solution for well-sorted sandstones. Jour. Sedim. Petrol., 50, 1347-1360.

Nielsen, B.L. \& Friis, H., 1985: Diagenesis of Middle Jurassic Haldager Formation Sandstone in the Danish Subbasin, North Jutland. Bull. geol. Soc. Denmark, 33, 273-285.

Ogunyomi, O., Martin, R.F. \& Hesse, R., 1981: Albite of secondary origin in Charny Sandstones, Quebec: a reevaluation. Jour. Sedim. Petrol., 51, 597-606.

Pittman, E.D., 1972: Diagenesis of quartz in sandstones as revealed by scanning electron microscopy. Jour. Sedim. Petrol., 42, 507519.

Pittman, E.D. \& Lumsden, D.N., 1968: Relationship between chlorite coatings on quartz grains and porosity, Spiro Sand, Oklahoma. Jour. Sedim. Petrol., 38, 668-676.

Priisholm, S., 1983: Geothermal reservoir rocks in Denmark. Danmarks geol. Unders., Årbog 1982, 73-86.

Priisholm, S. \& Christensen, S., 1985: Assessment of Geothermal Resources and Reserves in Denmark. Geological Survey of Denmark, series C, 2, 54 pp. 
Renton, J.J., Heald, M.T. \& Cecil, C.B., 1969: Experimental investigation of pressure solution of quartz. Jour. Sedim. Petrol., 39, 1107-1117.

Schmidt, B.J., 1985 (a): A coal petrographic source rock evaluation of the Rhaetic-Jurassic-Lower Cretaceous sediments of the Børglum 1 and Uglev 1 wells, Denmark. Bull. geol. Soc. Denmark, 33 , 239-252.

Schmidt, B.J., 1985 (b): Clay mineral investigation of the Rhaetic Jurassic-Lower Cretaceous sediments of the Børglum 1 and Uglev 1 wells. Bull. geol. Soc. Denmark, 34, 97-110.

Schmidt, V. \& McDonald, D.A., 1979: The role of secondary porosity in the course of sandstone diagenesis. in: Scholle, P.A. \& P.R. Schluger (Eds.): Aspects of Diagenesis, 175-207. S.E.P.M. Special Publication, 26.

Sibley, D.F. \& Blatt, H., 1976: Intergranular pressure solution and cementation of the Tuscarora Orthoquartzite. Jour. Sedim. Petrol., 46, 881-896.

Siebert, R.M., Moncure, G.K. \& Lahann, R.W., 1984: A theory of framework grain dissolution in sandstones. in: McDonald, D.A. \& R.C. Surdam (Eds): Clastic Diagenesis, A.A.P.G. Memoir 37, $163-175$.

Surdam, R.C., Boese, S.W. \& Crossey, L.J., 1984: The chemistry of secondary porosity. in: McDonald, D.A. \& R.C. Surdam (Eds): Clastic Diagenesis, A.A.P.G. Memoir 37, 127-149.

Thomsen, E., Lindgren, H. \& Wrang, P., 1983: Investigation of the source rock potential of Denmark. Geologie en Mijnbouw, 62, 221-239.

Thomson, A., 1959: Pressure solution and porosity. in: Ireland, H.A. (Ed): Silica in sediments, 92-110. S.E.P.M. Special Publication, 7.

Trurnit, P., 1968: Pressure solution phenomena in detrital rocks. Sedimentary Geology, 2, 89-114.

Walker, T.R., 1984: 1984 SEPM Presidential Address: Diagenetic albitization of potassium feldspar in arkosic sandstones. Jour. Sedim. Petrol., 54, 3-16.

Waugh, B., 1970: Formation of quartz overgrowths in the Penrith Sandstone (Lower Permian) of Northwest England as revealed by scanning microscopy. Sedimentology, 14, 309-320.

Wilson, M.D. \& Pittman, E.D., 1977: Authigenic clays in sandstones: Recognition and influence on reservoir properties and paleoenvironmental analysis. Jour. Sedim. Petrol., 47, 3-31.

Yde, E., 1983: En petrologisk undersøgelse af diageneseforholdene i Gassum Formationen fra Gassum 1, Farsø 1 og Års 1a boringerne. Unpubl. thesis, Dept. Geol., University of Aarhus, 137 pp. 
Plates 1-4 
PLATE 1

A. Partly dissolved feldspar grain with much intragranular porosity $(F)$ being partly included by large quartz overgrowth (Qo). Fars $\varnothing$ 1, $2875.35 \mathrm{~m}$.

B. Detail of $A$. Note small pits in the rhombohedral quartz faces after feldspar laths (arrowed). Fars $\varnothing$ 1, $2875,35 \mathrm{~m}$.

C. Partly dissolved feldspar grain. Note strong dependance on crystallography. Fars $\varnothing 1,2875.35 \mathrm{~m}$.

D. Broken and partly dissolved feldspar grain $(F d)$ with feldspar overgrowths (arrowed). Qo: authigenic quartz. Details in E-H. Aars 1 A, $3352.60 \mathrm{~m}$.

E. Detail of D. The crack in the feldspar grain is filled with authigenic quartz (Qo), and small euhedral feldspar crystals have formed on the partly dissolved feldspar grain (Fo). Aars $1 \mathrm{~A}, 3352.60 \mathrm{~m}$.

$F$. Detail of E. The minute euhedral feldspar crystals all have the same crystallographic orientation, indicating a common nucleus. Aars 1A, $3352.60 \mathrm{~m}$.

G. Detail of $D$. Authigenic quartz (Qo) growing in primary porosity and partly including the detrital feldspar (Fd). Small euhedral feldspar crystals on front surface of the feldspar. Aars $1 A, 3352.60 \mathrm{~m}$

$H$. Detail of $G$. Euhedral feldspar crystals on strongly leached surface of detrital feldspar. Aars 1A, $3352.60 \mathrm{~m}$. 
Plate 1
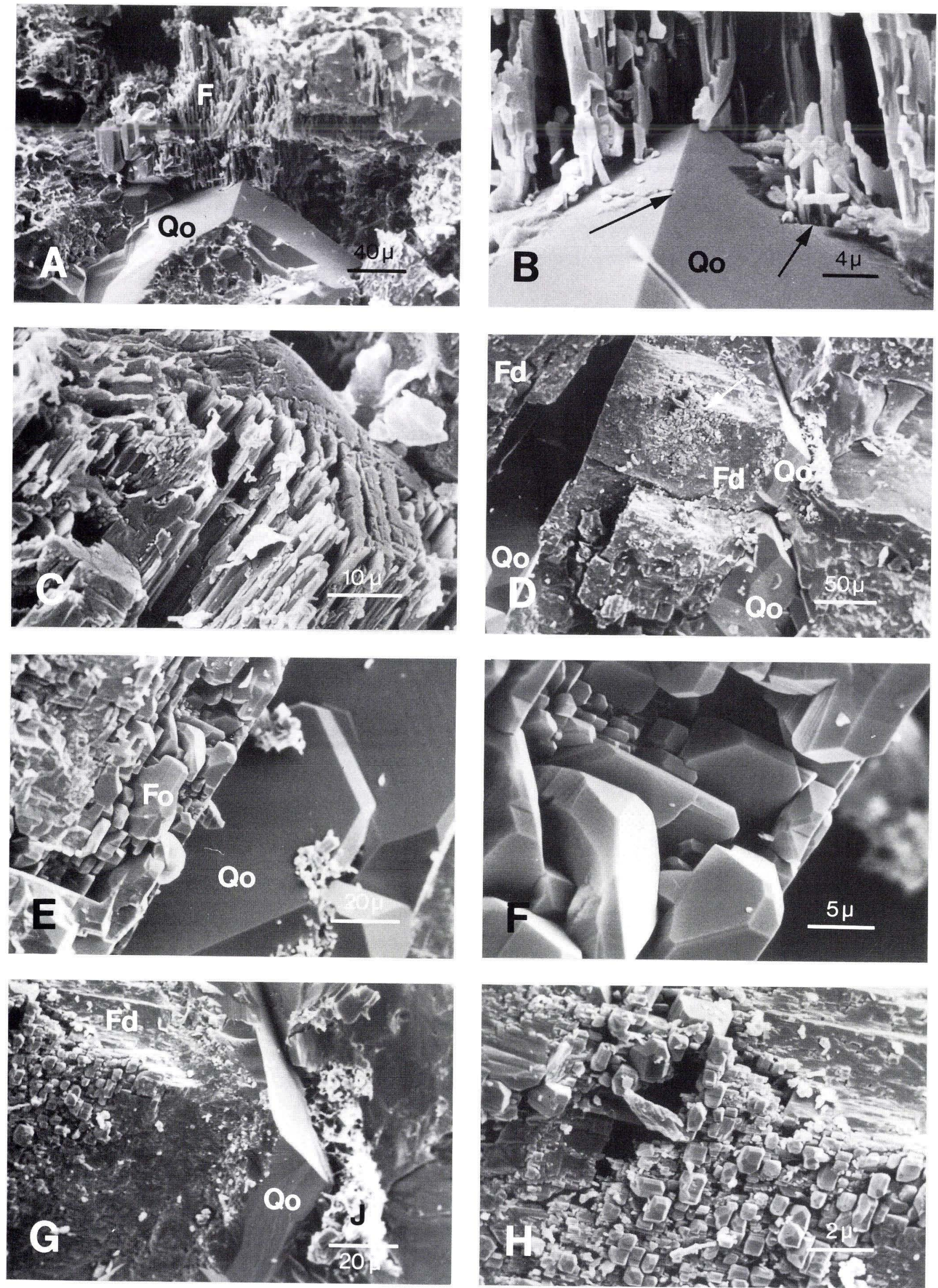
PLATE 2.

A. Quartz (Qo) and feldspar (Fo) overgrowths filling primary porosity. The quartz and feldspar overgrowths have included older, pore-filling kaolinite $(K)$. The feldspar overgrowth has identical optical properties with the detrital feldspar (Fd). A faint dust line separates the detrital quartz $(Q d)$ from the overgrowth. Aars $1 A, 3324.45 \mathrm{~m}$. Two polars.

$B$. Alkalifeldspar $(F d)$ with albite overgrowth $(F O)$. The overgrowth is partly including older porefilling kaolinite $(K)$. Aars $1 A$, 3351,72 m. Two polars.

C. Strongly dissolved detrital feldspar (center) with authigenic albite on intragranular skeletal remnants (arrowed). Although distinctly separated, the overgrowths have identical orientation, and compaction or collapse of the skaletal grain is negligible. Pore-filling kaolinite $(\mathrm{Kp})$ is restricted to primary porosity. Aars $1 \mathrm{~A}, 3275.40 \mathrm{~m}$.

D. Partly dissolved detrital feldspar ( $F d)$ with overgrowths (arrowed). Pore-filling kaolinite $(K)$ in primary porosity has partly restricted the growth of authigenic feldspar. Aars 1 A, $3275.40 \mathrm{~m}$.

E. Kaolinite in "oversize pore" $(K)$. Note framework positions of kaolinite aggregates. Strongly dissolved detrital feldspar (Fd). Aars $1 \mathrm{~A}, 3275.40 \mathrm{~m}$.

F. Kaolinite aggregate $(K)$ in framework position. Thisted $3,1218.20 \mathrm{~m}$.

$G$. Strongly dissolved feldspar (center) being partly included by quartz overgrowths (arrowed). Fjerritslev 2, $2304.00 \mathrm{~m}$. Analyzer: $53^{\circ}$.

H. Poikilotopic anhydrite (A) including high proportion of older pyrite (P). Gassum 1, $1633.11 \mathrm{~m}$. 
Plate 2
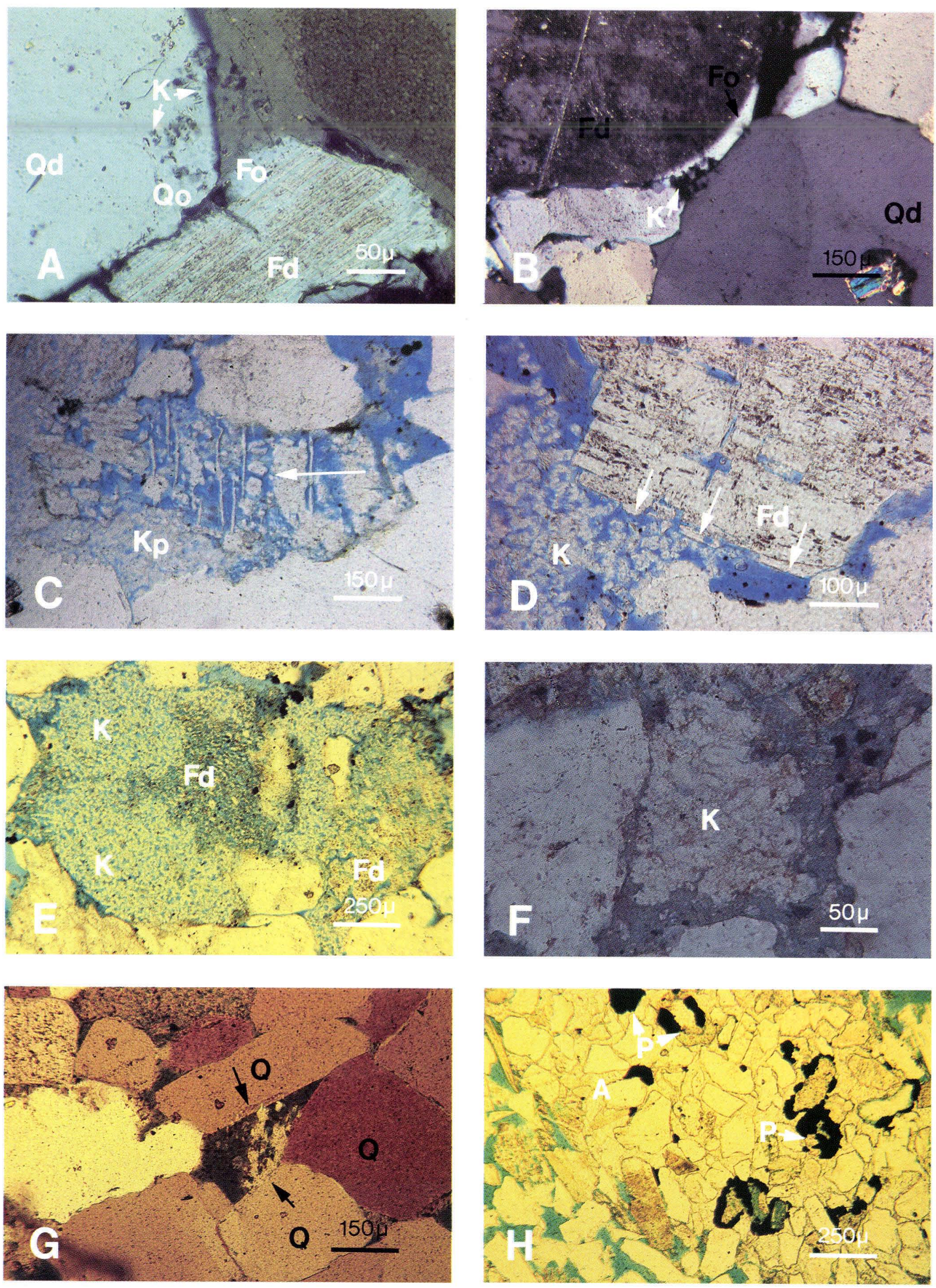


\section{PLATE 3}

A. Porelining chlorite (Chl) on detrital quartz $(Q d)$. The Chlorite is partly being covered by euhedral quartz (Qo). Fars $\varnothing 1$, $2868,84 \mathrm{~m}$.

B. Detail of $A$

C. Porelining authigenic clay (Chlorite?), partly included by younger quartz (Qo). Arrowed: small pits in quartz surface after clay. Fars $\varnothing$ 1, 2868,64 m.

D. Porelining chlorite (arrowed) and younger kaolinite $(K)$ being included quartz overgrowths (Qo). Aars $1 A, 3210.85 \mathrm{~m}$.

E. Pore filling kaolinite $(K)$ and younger illite is included in quartz overgrowths. Enlarged part in F. Aars $1 A, 3210.85 \mathrm{~m}$.

F. Detail of E. Hairy illite is included in younger quartz overgrowths (Q). Aars $1 A, 3210.85 \mathrm{~m}$.

$G$. Porelining chlorite (Chl) partly coverd by porefilling kaolinite $(K)$, both included by younger quartz Overgrowths (Qo). Aars $1 A, 3272.33 \mathrm{~m}$.

$H$. Hairy illite (I) included in quartz overgrowth $(Q o)$. The illite hairs are surrounded by small pits in the quartz surface (arrowed). Fjerritslev 2, $2304.00 \mathrm{~m}$. 

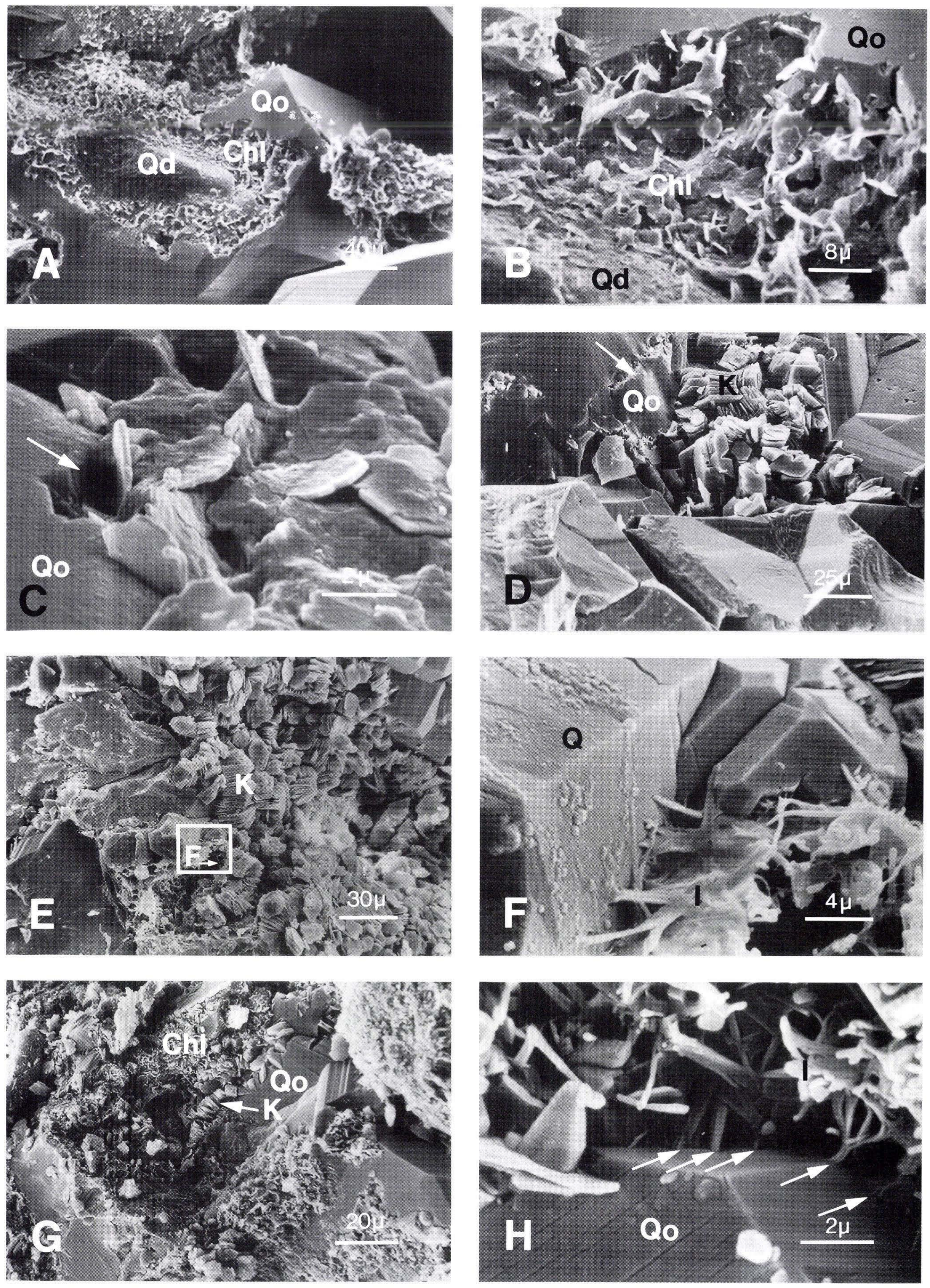
PLATE 4.

A. Porelining chlorite (Chl). The poreliner is missing at pressolved contact (arrowed). Fars $\varnothing$ 1, 2871.44 m. Two polars.

$B$. Sandstone with many pressolved contacts $(P c)$, porelining chlorite $(C h l)$ and quartz overgrowths $(Q o)$ on clean surfaces. Fars $\emptyset$ 1, 2869,53 m. Two polars.

C. Porelining chlorite (Chl) has been removed from part of a detrital quartz grain (Qd), and quartz overgrowth (Qo) has formed on the exposed part of the grain. Fars $\varnothing$ 1, $2869.53 \mathrm{~m}$. Two polars.

$D$. Broken detrital feldspar $(F d)$ with large quartz overgrowths $(Q o)$ entering the opened crack. Two polars.

E. Expanded mica with abundant euhedral siderite in interlamellar position (S). Aars $1 \mathrm{~A}, 3275.40 \mathrm{~m}$.

F. Spherolitic siderite with dense clustering of pyrite in central part. Thisted 3, $1185.40 \mathrm{~m}$.

G. Perthite $(F d)$ with albite overgrowths $(F O)$. The detrital grain has been marginally replaced by ankerite $(A)$. Fars $\emptyset 1,2901.80 \mathrm{~m}$. Analyzer $64^{\circ}$.

H. Skeletal remnant of feldspar (center) has been included in ankerite (A). Replacement of feldspar and quartz by the ankerite is negligible. Fars $\phi$ 1, $2874.00 \mathrm{~m}$. 

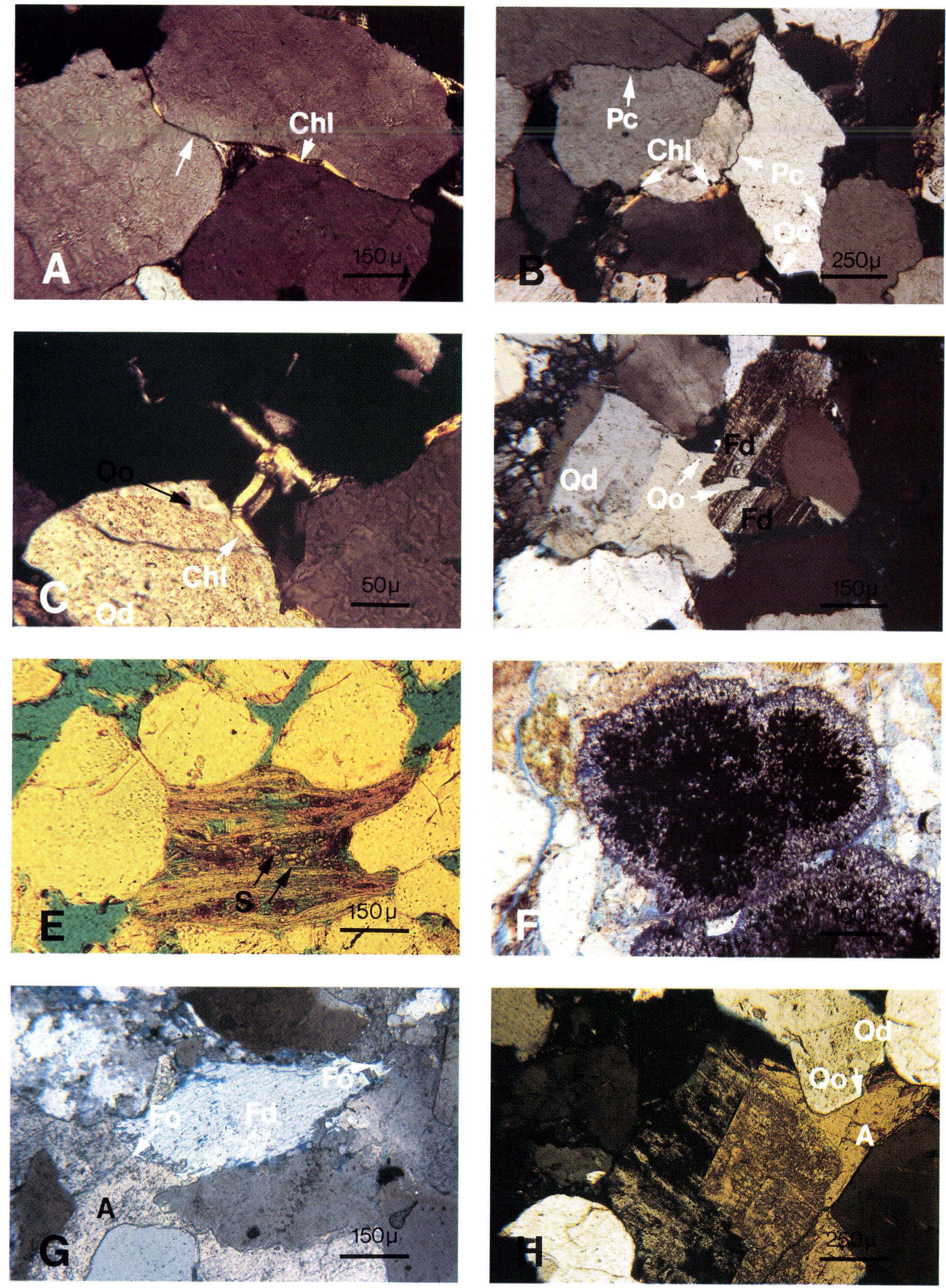
This paper outlines the diagenetic patterns in sandstones from the TriassicJurassic Gassum Formation within Jutland subcrops.

The paper forms an important contribution to the diagenetic studies on sediments within Danish areas. 